\title{
Retrieval of stratospheric and tropospheric BrO profiles and columns using ground-based zenith-sky DOAS observations at Harestua, $60^{\circ} \mathrm{N}$
}

\author{
F. Hendrick ${ }^{1}$, M. Van Roozendael ${ }^{1}$, M. P. Chipperfield ${ }^{2}$, M. Dorf ${ }^{3}$, F. Goutail ${ }^{4}$, X. Yang ${ }^{5}$, C. Fayt ${ }^{1}$, C. Hermans ${ }^{1}$, \\ K. Pfeilsticker ${ }^{3}$, J.-P. Pommereau ${ }^{4}$, J. A. Pyle ${ }^{5}$, N. Theys ${ }^{1}$, and M. De Mazière ${ }^{1}$ \\ ${ }^{1}$ Institut d'Aéronomie Spatiale de Belgique (IASB-BIRA), Brussels, Belgium \\ ${ }^{2}$ Institute for Atmospheric Science, School of Earth and Environment, University of Leeds, Leeds, UK \\ ${ }^{3}$ Institute for Environmental Physics, University of Heidelberg, Heidelberg, Germany \\ ${ }^{4}$ Service d'Aéronomie du CNRS, Verrières-le-Buisson, France \\ ${ }^{5}$ Centre for Atmospheric Science, Department of Chemistry, University of Cambridge, Cambridge, UK
}

Received: 1 June 2007 - Published in Atmos. Chem. Phys. Discuss.: 21 June 2007

Revised: 10 September 2007 - Accepted: 12 September 2007 - Published: 21 September 2007

\begin{abstract}
A profiling algorithm based on the optimal estimation method is applied to ground-based zenith-sky UV-visible measurements from Harestua, Southern Norway $\left(60^{\circ} \mathrm{N}, 11^{\circ} \mathrm{E}\right)$ in order to retrieve $\mathrm{BrO}$ vertical profiles. The sensitivity of the zenith-sky observations to the tropospheric $\mathrm{BrO}$ detection is increased by using for the spectral analysis a fixed reference spectrum corresponding to clear-sky noon summer conditions. The information content and retrieval errors are characterized and it is shown that the retrieved stratospheric profiles and total columns are consistent with correlative balloon and satellite observations, respectively. Tropospheric $\mathrm{BrO}$ columns are derived from profiles retrieved at $80^{\circ}$ solar zenith angle during sunrise and sunset for the 2000 2006 period. They show a marked seasonality with mean column value ranging from $1.52 \pm 0.62 \times 10^{13} \mathrm{molec} / \mathrm{cm}^{2}$ in late winter/early spring to $0.92 \pm 0.38 \times 10^{13} \mathrm{molec} / \mathrm{cm}^{2}$ in summer, which corresponds to $1.0 \pm 0.4$ and $0.6 \pm 0.2 \mathrm{pptv}$, respectively, if we assume that $\mathrm{BrO}$ is uniformly mixed in the troposphere. These column values are also consistent with previous estimates made from balloon, satellite, and other ground-based observations. Daytime (10:30 LT) tropospheric BrO columns are compared to the $p$-TOMCAT 3-D tropospheric chemical transport model (CTM) for the 20022003 period. $p$-TOMCAT shows a good agreement with the retrieved columns except in late winter/early spring where an underestimation by the model is obtained. This finding could be explained by the non-inclusion of sea-ice bromine sources in the current version of $p$-TOMCAT. Therefore the model cannot reproduce the possible transport of air-masses with enhanced $\mathrm{BrO}$ concentration due to bromine explosion
\end{abstract}

Correspondence to: $\mathrm{F}$. Hendrick

(franch@oma.be) events from the polar region to Harestua. The daytime stratospheric BrO columns are compared to the SLIMCAT stratospheric 3-D-CTM. The model run used in this study, which assumes $21.2 \mathrm{pptv}$ for the $\mathrm{Br}_{\mathrm{y}}$ loading (15 pptv for long-lived bromine species and additional $6 \mathrm{pptv}$ for very short-lived species (VSLS) added by a scaling of $\mathrm{CH}_{3} \mathrm{Br}$ ), significantly underestimates the retrieved $\mathrm{BrO}$ columns. A sensitivity study shows that a good agreement can only be obtained if 6 to 8 pptv accounting for VSLS are added directly (and not by a scaling of $\mathrm{CH}_{3} \mathrm{Br}$ ) to the SLIMCAT long-lived bromine species profile. This contribution of the VSLS to the total bromine loading is also consistent with recently published studies.

\section{Introduction}

Bromine monoxide $(\mathrm{BrO})$ is a key atmospheric trace gas known to cause significant ozone destruction in both the stratosphere and troposphere. In the stratosphere, $\mathrm{BrO}$ contributes to ozone depletion through its catalytic reactions with $\mathrm{ClO}, \mathrm{HO}_{2}, \mathrm{NO}_{2}$, and $\mathrm{O}$ (e.g., Lary, 1996). At mid-latitude these catalytic cycles account for about $25 \%$ of the ozone loss while in polar regions this contribution may reach $50 \%$, mainly through the $\mathrm{BrO} / \mathrm{ClO}$ cycle (Chipperfield and Pyle, 1998; Lee et al., 2002; Sinnhuber et al., 2006). BrO is also the most abundant inorganic bromine species during daytime $\left(\mathrm{BrO} / \mathrm{Br}_{\mathrm{y}} \sim 0.6\right.$ with $\left.\mathrm{Br}_{\mathrm{y}}=\mathrm{Br}+\mathrm{BrO}+\mathrm{BrONO}{ }_{2}+\mathrm{HBr}+\mathrm{HOBr}+\mathrm{BrCl}\right)$. The sources of inorganic bromine in the stratosphere are natural, with methyl bromide $\left(\mathrm{CH}_{3} \mathrm{Br}\right)$, and anthropogenic with $\mathrm{CH}_{3} \mathrm{Br}$ and halons. Several studies (Pfeilsticker et al., 2000; Salawitch et al., 2005; Sinnhuber et al., 2005, WMO 2007) have

Published by Copernicus Publications on behalf of the European Geosciences Union. 
suggested that the transport of very short-lived organic compounds like $\mathrm{CHBr}_{3}, \mathrm{CH}_{2} \mathrm{BrCl}, \mathrm{CHBrCl}_{2}$ or $\mathrm{CH}_{2} \mathrm{BrCH}_{2} \mathrm{Br}$ to the stratosphere would have a significant contribution (4 to $8 \mathrm{pptv}$ ) to the total stratospheric bromine loading. This could at least partly explain inconsistencies obtained between stratospheric $\mathrm{Br}_{\mathrm{y}}$ inferred from $\mathrm{BrO}$ observations (between $18 \pm 3$ and $21.5 \pm 3$ parts per trillion by volume, pptv (e.g., Schofield et al., 2006; Dorf et al., 2006, and references therein) and the delivery of bromine to the stratosphere by the long-lived species $\mathrm{CH}_{3} \mathrm{Br}$ and halons estimated to about 15 pptv (WMO, 2003).

In the troposphere, $\mathrm{BrO}$ also directly affects ozone by destroying it or by reducing its production (e.g., von Glasow et al., 2004). Large $\mathrm{BrO}$ enhancements associated with low ozone levels have been found in spring in the polar boundary layer by satellite and ground-based DOAS observations (e.g., Kreher et al., 1997; Wagner et al., 2001; Frieß et al., 2004). Frost flowers, which are highly saline crystals appearing on top of the sea ice surface, are believed to play a major role in the production of the reactive bromine at the origin of these so-called "bromine explosion events". High BrO mixing ratios associated with low ozone levels have been also detected in the marine boundary layer (Leser et al., 2003), over salt lakes (Hebestreit et al., 1999), and in volcanic plumes (Bobrowski et al., 2003). In the free troposphere, several satellite (e.g., Richter et al., 2002; Van Roozendael et al., 2002), balloon (Harder et al., 2000; Fitzenberger et al., 2000), and ground-based DOAS observations (e.g., Van Roozendael et al., 2002; Schofield et al., 2004 and 2006; Theys et al., 2007), have shown evidences for the presence of a global background of tropospheric BrO. However, there are still speculations about the $\mathrm{BrO}$ volume mixing ratio corresponding to this background: according the different observations, the tropospheric $\mathrm{BrO}$ vertical column amount can range from 0.3 to $3.7 \times 10^{13} \mathrm{molec} / \mathrm{cm}^{2}$, corresponding to $0.2-2.3 \mathrm{pptv}$ if we assume that $\mathrm{BrO}$ is uniformely mixed in the troposphere.

The ground-based DOAS (Differential Optical Absorption Spectroscopy) technique (Platt, 1994) has been extensively used to study and monitor ozone depletion in the stratosphere and more recently in the troposphere (see Hönninger et al. (2004) for a comprehensive description of the different applications of the DOAS technique). A significant part of this monitoring effort has been carried out through the UV-vis network of the NDACC (Network of the Detection of Atmospheric Composition Change, formerly NDSC). The NDACC/UV-vis network consists in more than 35 spectrometers operating from pole to pole and providing time-series of total vertical columns of $\mathrm{O}_{3}, \mathrm{NO}_{2}$, and, in a near future, of $\mathrm{BrO}$ (further information at http://www.ndsc. ncep.noaa.gov/). Since the early 1970s, several studies have shown the ability to retrieve information on the vertical distribution of trace gas species like $\mathrm{NO}_{2}$ and $\mathrm{O}_{3}$ from groundbased zenith-sky DOAS observations (Brewer et al., 1973; Noxon, 1975; McKenzie et al., 1991; Preston et al., 1997; Hendrick et al., 2004, and Denis et al., 2005). In most of the aforementioned studies, the retrieval algorithm was based on the Optimal Estimation Method (OEM), which is a widely used technique for solving atmospheric remote sensing inverse problems (Rodgers, 2000). In Schofield et al. (2004 and 2006), the OEM has been also applied to combined ground-based zenith-sky and direct sun observations in order to retrieve tropospheric and stratospheric $\mathrm{BrO}$ columns at Lauder $\left(45^{\circ} \mathrm{S}\right)$ and Arrival Height $\left(78^{\circ} \mathrm{S}\right)$. The sensitivity to the stratosphere was provided by the zenith-sky geometry, while the direct sun geometry ensured adequate sensitivity to the troposphere. Very recently in a theoretical study, Frieß et al. (2006) used the OEM to derive vertically-resolved information on atmospheric aerosols from Multi-AXis (MAX) DOAS measurements of the oxygen collision complex $\left(\mathrm{O}_{4}\right)$.

Here we report on the retrieval of the vertical distribution of $\mathrm{BrO}$ in the atmosphere using ground-based zenith-sky DOAS observations performed during the 2000-2006 period at the NDACC station of Harestua, Southern Norway $\left(60^{\circ} \mathrm{N}\right.$, $\left.11^{\circ} \mathrm{E}\right)$. The paper is divided into 6 parts. In the first part, the ground-based UV-visible observations and DOAS settings are described. Since the sensitivity of the zenith-sky measurements to the troposphere relies on the choice of an appropriate reference spectrum for the DOAS analysis, this point is extensively discussed. The second part is dedicated to the description of the profiling algorithm based on the OEM. In the third part, the $\mathrm{BrO}$ retrievals are characterized regarding the information content, error budget, and retrieval fit results. The consistency between $\mathrm{BrO}$ retrievals and correlative satellite and balloon data is verified in the fourth part. In the fifth part, tropospheric and stratospheric $\mathrm{BrO}$ columns are derived from the retrieved profiles. The consistency of the tropospheric columns with previously published estimates is also discussed. Finally, in the sixth part, the tropospheric and stratospheric columns are compared to model calculations.

\section{Ground-based DOAS observations}

Ground-based zenith-sky UV-visible observations have been continuously performed by IASB-BIRA at the NDACC station of Harestua since 1998. The instrument consists of two zenith-sky looking grating spectrometers using cooled photodiode-array detectors and recording radiances in the UV and visible regions (Van Roozendael et al., 1998). Spectral range and resolution of the UV spectrometer used for $\mathrm{BrO}$ measurements are $330-390 \mathrm{~nm}$ and $0.6 \mathrm{~nm}$ FWHM, respectively. Measured zenith radiance spectra are analyzed using the DOAS technique (Platt, 1994). BrO differential slant column densities (DSCDs), which are the direct product of the DOAS analysis, are retrieved in the $345-359 \mathrm{~nm}$ wavelength range, taking into account the spectral signature of $\mathrm{NO}_{2}, \mathrm{O}_{3}, \mathrm{O}_{4}, \mathrm{OClO}$, and the Ring effect. The BrO crosssections are from Wilmouth et al. (1999). A typical example of a BrO DOAS fit is presented in Fig. 1. More details on the DOAS settings can be found in Aliwell et al. (2002) and 
Theys et al. (2007). It should also be noted that the instrument has been validated through several NDACC campaigns: Lauder 1992 (Hoffman et al., 1995), OHP 1996 (Roscoe et al., 1999; Aliwell et al., 2002), and Andøya 2003 (Vandaele et al., 2005).

In the present study, absolute $\mathrm{BrO}$ SCDs covering the 2000-2006 period are provided as input to the profiling algorithm. These are evaluated using a fixed noon summer spectrum as reference and the residual amount of $\mathrm{BrO}$ in the reference spectrum (RSCD) is calculated prior to the profiling step. This is in contrast to the $\mathrm{NO}_{2}$ profile retrievals performed at Harestua (Hendrick et al., 2004) where zenith radiance spectra were analyzed with respect to daily reference spectra and the $\mathrm{NO}_{2}$ RSCDs were directly fitted by the profiling algorithm. Here, a fixed reference spectrum is used for each year of measurement data. Clear-sky noon summer reference spectra are chosen in order to maximize the signal to noise ratio of the measurements and to minimize the residual absorption by $\mathrm{BrO}$ in both the troposphere and the stratosphere since the different light paths through the atmosphere and hence expected $\mathrm{BrO}$ absorption are smallest at noon. Therefore, the use of such fixed reference spectra significantly enhances the sensitivity of the measurements to the tropospheric $\mathrm{BrO}$ content (see also Sect. 4.1).

The BrO RSCDs corresponding to the selected reference spectra are estimated using a two-step method. The principle of this method is to use two different approaches to calculate the total $\mathrm{BrO}$ vertical column densities (VCDs): one approach which depends on the $\mathrm{BrO}$ photochemistry but not on the BrO RSCD (photochemically-modified Langleyplot analysis) and a second approach which depends on the $\mathrm{BrO}$ RSCD but not on the BrO photochemistry. Evidently, both approaches should give identical total $\mathrm{BrO}$ VCDs and this is used to constrain the BrO RSCD value. In the first step, the total $\mathrm{BrO}$ vertical columns (VCDs) are calculated at $75^{\circ}$ solar zenith angle (SZA) for both sunrise and sunset for each day of the April-August period (where the SZA at local noon at Harestua is smaller than $50^{\circ} \mathrm{SZA}$ ) using a modified Langley-plot analysis taking into account the diurnal variation of stratospheric $\mathrm{BrO}$ (see Eq. 1). $75^{\circ} \mathrm{SZA}$ is chosen to minimize the impact of a possible diurnal variation of tropospheric $\mathrm{BrO}$ on the Langley-plot analysis.

$$
\operatorname{DSCD}(\theta)=-\mathrm{RSCD}+\mathrm{VCD}_{\text {total }, 75^{\circ} \mathrm{SZA}} \mathrm{AMF}_{\text {total }, 75^{\circ} \mathrm{SZA}}(\theta)
$$

where $\operatorname{DSCD}(\theta)$ is the differential $\operatorname{SCD}$ at the SZA of $\theta$, RSCD the residual amount in the reference spectrum, $\mathrm{VCD}_{\text {total }} 75^{\circ} \mathrm{SZA}$ the total $\mathrm{BrO} \mathrm{VCD}$ at $75^{\circ} \mathrm{SZA}$ (slope of the Langley plot), and $\mathrm{AMF}_{\text {total }} 75^{\circ} \mathrm{SZA}(\theta)$ is the total photochemical AMF at SZA of $\theta$ and is given by the following expression:

$$
\begin{aligned}
& \operatorname{AMF}_{\text {total }, 75^{\circ} \mathrm{SZA}}(\theta) \\
& \quad=\mathrm{f}_{\text {tropo }} \mathrm{AMF}_{\text {tropo }}(\theta)+\left(1-\mathrm{f}_{\text {tropo }}\right) \mathrm{AMF}_{\text {strato, } 75^{\circ} \mathrm{SZA}}(\theta)
\end{aligned}
$$

where $\mathrm{f}_{\text {tropo }}$ is the contribution of the troposphere to the total $\mathrm{BrO}$ column, $\mathrm{AMF}_{\text {tropo }}(\theta)$ the tropospheric AMF at the SZA

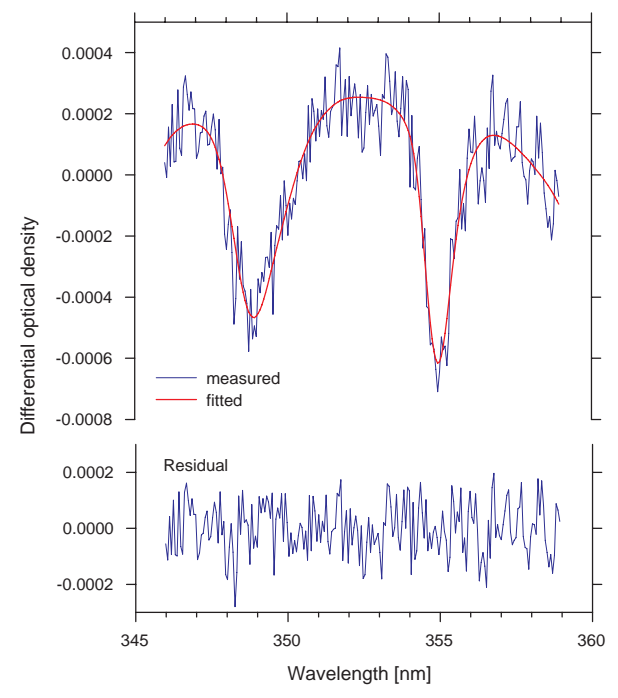

Fig. 1. Example of a BrO DOAS fit at Harestua (1 June 2004, $86^{\circ}$ SZA).

of $\theta$, and $\mathrm{AMF}_{\text {strato, } 75^{\circ} \mathrm{SZA}}(\theta)$ is the stratospheric $\mathrm{AMF}$ at the SZA of $\theta$ photochemically modified with respect to $75^{\circ} \mathrm{SZA}$ $\left(\mathrm{AMF}_{\text {strato, } 75^{\circ} \mathrm{SZA}}(\theta)=\operatorname{SCD}_{\text {strato }}(\theta) / \mathrm{VCD}_{\text {strato }}\left(75^{\circ}\right)\right)$. Using such photochemically modified AMFs allows to remove the change in the VCDs due to the photochemistry from the AMFs.

Both tropospheric and stratospheric AMFs are calculated using the radiative transfer model (RTM) UVspec/DISORT (see Sect. 3). In case of tropospheric AMFs, a constant $\mathrm{BrO}$ concentration of $1 \times 10^{7} \mathrm{molec} / \mathrm{cm}^{3}$ in the whole troposphere is used. Stratospheric photochemical AMFs are generated using $\mathrm{BrO}$ diurnal variation calculated by the stacked box photochemical model PSCBOX (see Sect. 3).

The contribution of the troposphere to the total $\mathrm{BrO}$ column appearing in Eq. (2), $\mathrm{f}_{\text {tropo }}$, is adjusted in order to get photochemically-modified Langley plots independent of the considered SZA range. Five SZA ranges $\left(50-75^{\circ}, 50-77.5^{\circ}\right.$, $50-80^{\circ}, 50-82.5^{\circ}$, and $50-85^{\circ}$ ) and four tropospheric contributions relative to the total atmospheric $\operatorname{BrO} \operatorname{VCD}(0,20$, 30 , and 40\%) are investigated. In Fig. 2, the ratio between the mean of $\mathrm{BrO}$ VCDs calculated for the 2000-2006 period in the different SZA ranges at sunset and the mean of $\mathrm{BrO}$ VCDs estimated in the $50-75^{\circ} \mathrm{SZA}$ range (taken as reference) is plotted as a function of the upper limit of the different SZA ranges. We see that the $\mathrm{BrO}$ VCD calculated for a SZA of $75^{\circ}$ becomes almost independent of the SZA range selected for the Langley-plot analysis when the tropospheric contribution to the total column $\mathrm{f}_{\text {tropo }}$ reaches 30 $40 \%$ (impact of the SZA range smaller than 5\%). Therefore we have chosen to fix $\mathrm{f}_{\text {tropo }}$ to $30 \%$ for the calculation of $\operatorname{AMF}_{\text {total }, 75^{\circ} \mathrm{SZA}}(\theta)$. Figure 3 shows an example of Langley plots obtained with $\mathrm{f}_{\text {tropo }}$ fixed to 0 and $30 \%$. The marked curvature found when using a $\mathrm{f}_{\text {tropo }}$ value of $0 \%$ (blue curve) 
Table 1. Residual amount of BrO in the selected reference spectra (RSCDs) estimated using three SZA ranges $\left(50-75^{\circ}\right.$, 50-80 ${ }^{\circ}$, and $50-$ $85^{\circ} \mathrm{SZA}$ ) for a tropospheric contribution to the total BrO column amount of $30 \%$. Errors due to the choice of the SZA range and to the uncertainties on $\mathrm{f}_{\text {tropo }}$ and the shape of the $\mathrm{BrO}$ profile in the troposphere are given. The total error is calculated by adding the three errors in quadrature.

\begin{tabular}{ccccccc}
\hline Year & $\begin{array}{c}\text { Julian day of } \\
\text { ref. spectrum }\end{array}$ & $\begin{array}{c}\text { Mean } \\
\text { RSCD }\end{array}$ & $\begin{array}{c}\text { Error due to } \\
\text { SZA range }\end{array}$ & $\begin{array}{c}\text { Error due to } \\
\mathrm{f}_{\text {tropo factor }} \\
\left(\times 10^{13} \mathrm{molec}_{\mathrm{cm}}{ }^{2}\right)\end{array}$ & $\begin{array}{c}\text { Error due to } \\
\text { profile shape }\end{array}$ & Total error \\
\hline 2000 & 172 & 5.96 & 0.10 & 0.92 & 0.50 & $1.05(18 \%)$ \\
2001 & 186 & 4.94 & 0.07 & 0.89 & 0.34 & $0.96(19 \%)$ \\
2002 & 200 & 7.98 & 0.09 & 0.91 & 0.36 & $0.98(12 \%)$ \\
2003 & 197 & 6.80 & 0.13 & 0.95 & 0.47 & $1.07(16 \%)$ \\
2004 & 202 & 6.83 & 0.29 & 0.98 & 0.39 & $1.09(16 \%)$ \\
2005 & 221 & 10.38 & 0.23 & 1.02 & 0.34 & $1.10(11 \%)$ \\
2006 & 161 & 5.44 & 0.65 & 1.02 & 0.47 & $1.30(24 \%)$ \\
\hline
\end{tabular}

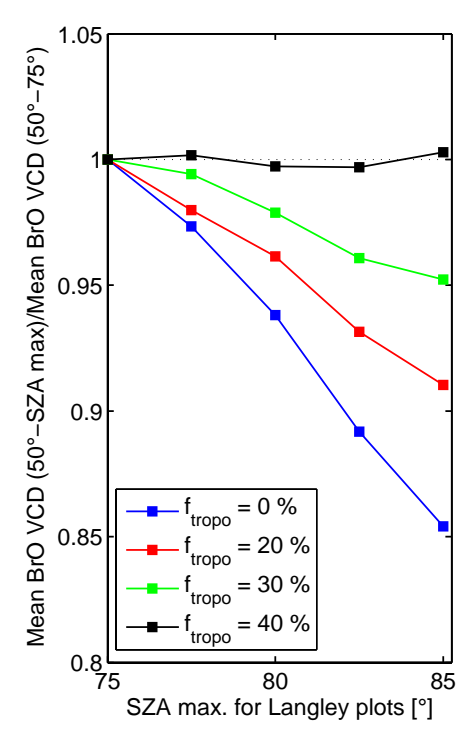

Fig. 2. Impact of the SZA range used in the Langley-plot analyses on the calculated $\mathrm{BrO}$ VCDs for different tropospheric contributions to the total $\mathrm{BrO}$ column $(0,20,30$, and $40 \%)$. Mean $\mathrm{BrO}$ VCDs calculated at sunset for the 2000-2006 period using five SZA ranges for the Langley-plot analyses $\left(50-75^{\circ}, 50-77.5^{\circ}, 50-80^{\circ}\right.$, $50-82.5^{\circ}$, and $50-85^{\circ}$ ) are plotted as a function of the upper limit of the different SZA ranges. Mean BrO VCDs are normalized by the values obtained for the $50-75^{\circ} \mathrm{SZA}$ range.

results from a mismatch in the shape of the $\mathrm{BrO}$ profile used to calculate AMFs and we see that a $\mathrm{f}_{\text {tropo }}$ value of $30 \%$ significantly improves the linearity of the Langley plot. It should be noted that similar results are obtained for sunrise $\mathrm{BrO}$ data.

In the second and last step, total $\mathrm{BrO}$ VCDs at $75^{\circ} \mathrm{SZA}$ are calculated for each day and at both sunrise and sunset using non-photochemically modified AMFs at $75^{\circ} \mathrm{SZA}$ :

$\mathrm{VCD}_{\text {total }, 75^{\circ} \mathrm{SZA}}=\left(\operatorname{DSCD}\left(75^{\circ}\right)+\mathrm{RSCD}\right) / \mathrm{AMF}_{\text {total }}\left(75^{\circ}\right)$

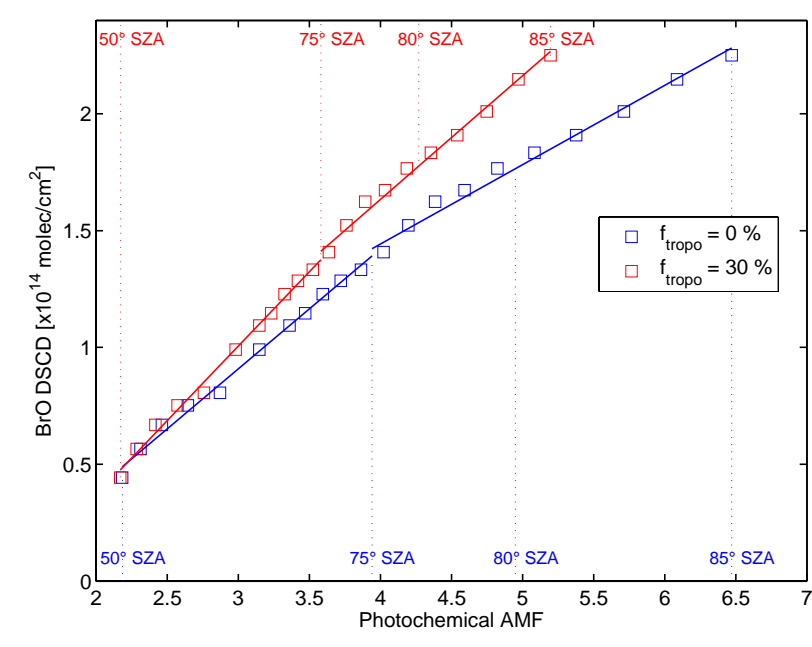

Fig. 3. Typical example of Langley-plot analyses obtained for the 24 April 2003 sunset case using a tropospheric contribution to the total BrO column of 0 (blue squares) and $30 \%$ (red squares). A $\mathrm{f}_{\text {tropo }}$ value of $30 \%$ significantly improves the linearity of the Langley plot.

where $\mathrm{AMF}_{\text {total }}\left(75^{\circ}\right)=\mathrm{f}_{\text {tropo }} \mathrm{AMF}_{\text {tropo }}\left(75^{\circ}\right)+\left(1-\mathrm{f}_{\text {tropo }}\right)$ $\operatorname{AMF}_{\text {strato }}\left(75^{\circ}\right)$ and with $\mathrm{f}_{\text {tropo }}$ fixed to $30 \%$.

RSCD in Eq. (3) is then fitted in order to get the best match between the $\mathrm{BrO} \mathrm{VCD}_{\text {total }}, 75^{\circ} \mathrm{SZA}$ calculated using Eqs. (1) and (3), respectively. Figure 4 shows an example of fit results (obtained for the year 2004). The BrO RSCDs estimated for each reference spectrum and averaged over three different SZA ranges $\left(50-75^{\circ}, 50-80^{\circ}\right.$, and $\left.50-85^{\circ}\right)$ for the Langley-plot analyses (Eq. 1) are presented in Table 1. Mean $\mathrm{BrO}$ RSCD values are added to the BrO DSCDs in order to obtain the absolute BrO SCDs that are used by the retrieval algorithm. In addition to the error on BrO RSCDs associated to the choice of the SZA range for the Langley-plot analyses, we have investigated the impact of two other error sources: 
the uncertainties on $\mathrm{f}_{\text {tropo }}$ and on the shape of the $\mathrm{BrO}$ profile used for the calculation of $\mathrm{AMF}_{\text {tropo. }}$. In order to achieve that, Langley-plot analyses have been performed by taking a $f_{\text {tropo }}$ value of 20 and $40 \%$ instead of $30 \%(30 \% \pm 10 \%)$ and for the second parameter, by using a Gaussian profile shape for $\mathrm{BrO}$ in the troposphere (peak at $5 \mathrm{~km}$, full width at half maximum (FWHM): $4 \mathrm{~km}$ ) instead of constant $\mathrm{BrO}$ concentration in the whole troposphere as in the standard Langleyplot analyses. These errors have been calculated for each year and are presented in Table 1. It appears that the total error on BrO RSCDs is in the $11-25 \%$ range.

\section{Retrieval algorithm}

The retrieval algorithm used here is the IASB-BIRA $\mathrm{NO}_{2}$ profiling algorithm adapted to $\mathrm{BrO}$. Since a detailed description of this algorithm can be found in Hendrick et al. (2004), only the main features will be given in the present section.

The inversion method employed is the Optimal Estimation (OEM; Rodgers, 2000). In this method, a profile $\widehat{\mathbf{x}}$ is retrieved given an a priori profile $\mathbf{x}_{\mathbf{a}}$, the measurements $\mathbf{y}$ (here, a set of absolute BrO SCDs as a function of SZA), their respective uncertainty covariance matrices $\left(\mathbf{S}_{\mathbf{a}}\right.$ and $\left.\mathbf{S}_{\varepsilon}\right)$, and the matrix $\mathbf{K}$ of the weighting functions. Since $\mathrm{BrO}$ is an optically thin absorber, the OEM for the linear case can be considered:

$\widehat{\mathbf{x}}=\mathbf{x}_{a}+\mathbf{S}_{a} \mathbf{K}^{T}\left(\mathbf{K S}_{a} \mathbf{K}^{T}+\mathbf{S}_{\varepsilon}\right)^{-1}\left(\mathbf{y}-\mathbf{K} \mathbf{x}_{a}\right)$ with $\mathbf{K}=\frac{\partial \mathbf{y}}{\partial \mathbf{x}}(4)$

The weighting functions indicate the sensitivity of the measurements to a change in the vertical profile. The matrix $\mathbf{K}$ is determined by consecutively perturbing each layer of the a priori profile and recalculating the set of measurements using the so-called forward model which describes the physics of the measurements. Here, the forward model consists in the stacked box photochemical model PSCBOX (Errera and Fonteyn, 2000; Hendrick et al., 2004) coupled to the RTM UVspec/DISORT (Mayer and Kylling, 2005). A photochemical model is required to reproduce the effect of the rapid variation of the $\mathrm{BrO}$ concentration at twilight. It also allows us to convert the retrieved profile to any SZA. The RTM is used to calculate slant column abundances from the BrO concentrations predicted by the photochemical model. PSCBOX has been described in details in Hendrick et al. (2004). Nevertheless, it is useful to mention here that (1) PSCBOX is daily initialised at 20 independent altitude levels (between $\sim 10$ and $\sim 55 \mathrm{~km}$ altitude) with 00:00 UT pressure, temperature, and chemical species profiles from the SLIMCAT 3D chemical transport model (Chipperfield, 1999 and 2006; see also Sect. 7), and (2) Updated kinetic and photochemical data are taken from the JPL 2006 compilation (Sander et al., 2006). Concerning the RTM UVspec/DISORT, it includes a treatment of multiple scattering in a pseudo-spherical geometry approximation. The variation of the $\mathrm{BrO}$ concentration
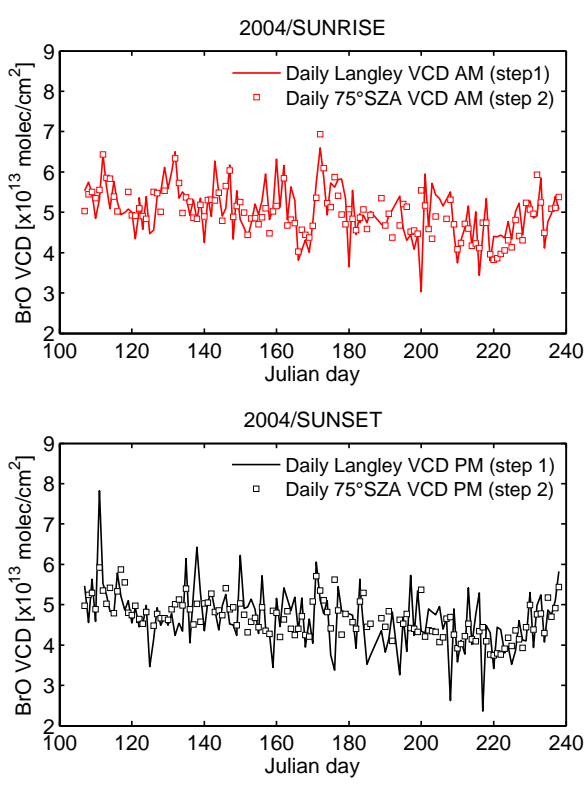

Fig. 4. Example of fit results obtained in the estimation of $\mathrm{BrO}$ RSCD (year 2004; upper plot for sunrise and lower plot for sunset). BrO RSCD in Eq. (3) is adjusted in order to get the best match between BrO VCDs at $75^{\circ}$ SZA calculated using Eq. (1) (step 1) and 3 (step 2). The $\mathrm{f}_{\text {tropo }}$ value is fixed to $30 \%$ and $50-80^{\circ}$ is the chosen SZA range for the Langley-plot analysis.

along the light-path is also taken into account since it has a large impact on the calculation of the slant column densities (Sinnhuber et al., 2002). The wavelength for RTM calculations was fixed to $352 \mathrm{~nm}$ and the ground albedo to $25 \%$. Concerning the aerosol extinction profile, it has been constructed from the aerosol model of Shettle (1989) included in UVspec/DISORT. In the stratosphere, the aerosol settings correspond to typical background conditions while in the boundary layer and troposphere, settings representative of a rural environment have been used (mixture of water soluble and dust-like aerosols). More details on the RTM UVspec/DISORT can be found in Hendrick et al. (2004) and Mayer and Kylling (2005). Both photochemical and radiative transfer models have been validated through several comparison exercises (Hendrick et al., 2000 and 2006; Wagner et al., 2007). Concerning the altitude grid, our retrieval is performed on a layer basis in the $0-90 \mathrm{~km}$ altitude range with a layer thickness of $2 \mathrm{~km}$.

The present retrieval problem is ill-conditioned for two reasons: (1) There exists more elements in the vector $\boldsymbol{x}$ than independent measurements, and (2) the error of some components of the measurements vector $\boldsymbol{y}$ can be large enough that these components become useless (null space of the measurements Rodgers, 2000). Points (1) and (2) lead to the lack of a unique solution of the retrieval problem and therefore, a priori constraints are necessary to reject unrealistic profiles that may be consistent with the measurements. In the 


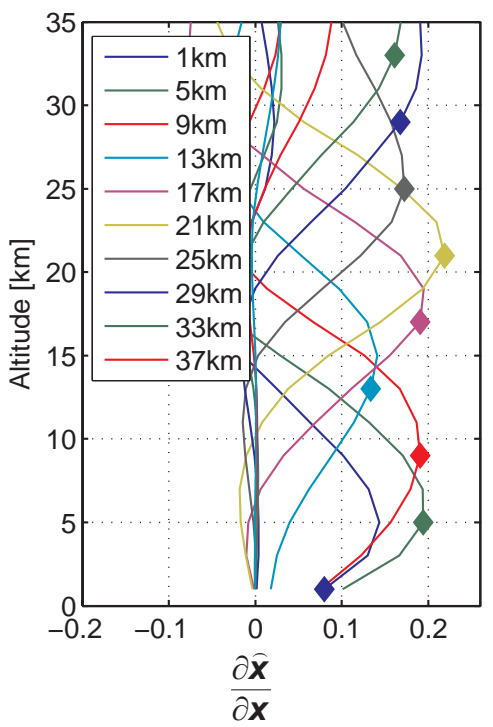

Fig. 5. Typical example of ground-based $\mathrm{BrO}$ averaging kernels. These were calculated for the Harestua 12 July 2004 sunrise retrieval. Plain diamonds indicate the altitude at which each averaging kernel should peak in an ideal case.

present study, the a priori profile (defined as concentration) is constructed as follows: in the stratosphere, the output of the photochemical model PSCBOX at the SZA of the retrieval is taken as a priori. It should be noted that the $\mathrm{BrO}$ diurnal variation is also provided as a priori information (output of the photochemical model PSCBOX) and is not directly retrieved by the algorithm as in Schofield et al. (2004 and 2006). Due to the uncertainties on the vertical distribution and the diurnal variation of $\mathrm{BrO}$ in the troposphere, a constant tropospheric $\mathrm{BrO}$ concentration of around $1 \times 10^{7} \mathrm{molec} / \mathrm{cm}^{3}$ is chosen for the construction of the a priori profile at local noon and the diurnal variation of this profile is assumed to be the same as the one given by the photochemical model PSCBOX in the lower stratosphere. Our approach for the construction of the a priori tropospheric profile is similar to the one used by Schofield et al. (2004).

The measurement covariance matrix $\mathbf{S}_{\varepsilon}$ is constructed by placing the square of the statistical errors on the BrO DOAS fitting along its diagonal, due to the domination of the DOAS fitting residuals by the random noise of the detector. The a priori covariance matrix $\mathbf{S}_{a}$ is empirically determined in order to ensure a good fit of the measurements without overfitting them. An error of $85 \%$ is chosen for the stratospheric part of the a priori profile. This value is found as the threshold value above which undesired oscillations in the retrieved profiles can occur. In the troposphere, an error of $100 \%$ is chosen in order to reduce the weight of a priori information and therefore to give to the algorithm large freedom to move away from the a priori profile. $\mathbf{S}_{a}$ also contains extradiagonal terms accounting for correlations between $\mathrm{BrO}$ val- ues at different altitude levels. These terms were added as Gaussian functions as in Hendrick et al. (2004).

\section{Characterisation of the retrievals}

\subsection{Information content analysis}

The averaging kernel matrix $\mathbf{A}$ is a key parameter for the characterization of the retrievals. The averaging kernels which are the rows of the A matrix - express the sensitivity of the retrieved profile $\widehat{\mathbf{x}}$ with respect to the true atmospheric profile $\mathbf{x}$ and are derived using the following expression (Rodgers, 2000):

$\mathbf{A}=\frac{\partial \widehat{\mathbf{x}}}{\partial \mathbf{x}}=\left(\mathbf{K}^{T} \mathbf{S}_{\varepsilon}^{-1} \mathbf{K}+\mathbf{S}_{a}^{-1}\right)^{-1} \mathbf{K}^{T} \mathbf{S}_{\varepsilon}^{-1} \mathbf{K}$.

Typical BrO ground-based UV-visible averaging kernels are shown in Fig. 5. The FWHM of a given averaging kernel provides a rough estimate of the vertical resolution at the target altitude. From the examination of the averaging kernels corresponding to several dozens of $\mathrm{BrO}$ retrievals, it is found that the vertical resolution is $8-10 \mathrm{~km}$ at best, the best resolution being obtained below $25 \mathrm{~km}$ altitude. The trace of the averaging kernel matrix gives the number of degrees of freedom for the signal, which is an estimate of the number of independent pieces of information contained in the measurements (Rodgers, 2000). Typical values for the trace of A are close to 3.5. That means that there are roughly 3 independent pieces of information in the measurements. Figures 5 also shows that the averaging kernels in the altitude range corresponding to the troposphere peak reasonably at their nominal altitude, indicating that our $\mathrm{BrO}$ retrievals are effectively sensitive to the troposphere.

Tests on the impact of the a priori profile on the retrieval can also give qualitative indications concerning the information content.

Two tests were performed: in the first one, the standard a priori profile was multiplied by a factor of two and in the second test, the shape of the a priori profile was modified: the standard a priori profile peaking at $15 \mathrm{~km}$ altitude was replaced by a new a priori profile peaking at $19 \mathrm{~km}$. The results of these tests, presented in Fig. 6, show that the impact of the a priori profile is small: the profiles retrieved using the modified a priori profiles are similar to those retrieved with the standard a priori profiles. This indicates that the information on the vertical distribution of $\mathrm{BrO}$ contained in the measurements is significant.

\subsection{Error budget}

The error analysis is performed as for the $\mathrm{NO}_{2}$ profile retrieval at Harestua (see Hendrick et al., 2004). In brief, the total retrieval error is given by the sum of three errors: the smoothing error, the retrieval noise, and the forward model 
Table 2. Forward model parameters, their relative errors, and the corresponding forward model parameter errors averaged for the $2000-2006$ period. The change in parameters followed by an asterisk (*) corresponds to their variability in March for the 2000-2004 period estimated from the output of the stacked box photochemical model PSCBOX. For the temperature, $10 \mathrm{~K}$ is the variability in March at $30 \mathrm{hPa}$ (about $23 \mathrm{~km}$ of altitude) derived from the temperature profiles used to initialize both photochemical and radiative transfer models. Concerning the aerosols, 50\% corresponds roughly to the estimated uncertainty in the modeled background aerosol surface area in PSCBOX. The error due to the use of a ground albedo of 0.25 is taken from Preston et al. (1997).

\begin{tabular}{lllcc}
\hline Parameter & $\begin{array}{l}\text { Model (photo- } \\
\text { chemical or } \\
\text { radiative) }\end{array}$ & $\begin{array}{l}\text { Change in } \\
\text { parameter }\end{array}$ & $\begin{array}{c}\text { Tropospheric column } \\
\left(\times 10^{13} \mathrm{molec} / \mathrm{cm}^{2}\right)\end{array}$ & $\begin{array}{c}\text { Stratospheric column } \\
\left(\times 10^{13} \mathrm{molec} / \mathrm{cm}^{2}\right)\end{array}$ \\
\hline $\mathrm{O}_{3} *$ & Photochemical & $\pm 12 \%$ & 0.007 & 0.07 \\
$\mathrm{O}_{3} *$ & Radiative & $\pm 12 \%$ & 0.0007 & 0.0001 \\
$\mathrm{BrONO}_{2} *$ & Photochemical & $\pm 19 \%$ & 0.07 & 0.29 \\
$\mathrm{HOBr}^{*}$ & Photochemical & $\pm 32 \%$ & 0.12 & 0.24 \\
$\mathrm{BrCl}^{*}$ & Photochemical & $+200 \%$ & 0.10 & 0.17 \\
Aerosols & Photochemical & $\pm 50 \%$ & 0.02 & 0.09 \\
Aerosols & Radiative & $\pm 50 \%$ & 0.01 & 0.004 \\
Temperature* & Photochemical & $\pm 10 \mathrm{~K}$ & 0.03 & 0.39 \\
Temperature* & Radiative & $\pm 10 \mathrm{~K}$ & 0.05 & 0.09 \\
Albedo & Radiative & +0.45 & 0.13 & 0.04 \\
\hline & Total & & 0.22 & 0.59 \\
\hline
\end{tabular}

Table 3. Error budget (in \%) for the retrieval of tropospheric and stratospheric BrO columns. The errors correspond to the columns retrieved at $80^{\circ}$ SZA during sunrise and sunset (see Table 5 in Sect. 6). Systematic and total retrieval errors are added in quadrature in order to give the total error on the columns.

\begin{tabular}{|c|c|c|c|c|c|}
\hline & & \multicolumn{2}{|c|}{ Tropospheric column (\%) } & \multicolumn{2}{|c|}{ Stratospheric column (\%) } \\
\hline & & $\mathrm{AM}$ & $\mathrm{PM}$ & $\mathrm{AM}$ & $\mathrm{PM}$ \\
\hline \multicolumn{2}{|l|}{ Smoothing error } & 23.9 & 22.1 & 4.1 & 3.8 \\
\hline \multicolumn{2}{|l|}{ Retrieval noise } & 22.4 & 21.6 & 4.0 & 3.8 \\
\hline \multicolumn{2}{|c|}{ Forward model parameter error } & 17.9 & 19.6 & 17.6 & 19.1 \\
\hline \multicolumn{2}{|c|}{ Total retrieval error } & 37.3 & 36.6 & 18.5 & 19.8 \\
\hline \multirow{3}{*}{$\begin{array}{l}\text { Systematic errors } \\
\text { Systematic + total }\end{array}$} & $\mathrm{BrO} \mathrm{XS}$ in DOAS fit & $<10$ & $<10$ & $<10$ & $<10$ \\
\hline & $\mathrm{BrO}$ RSCD & 13.4 & 14.0 & 3.0 & 3.4 \\
\hline & Systematic + total retrieval errors & 40.9 & 40.4 & 21.2 & 22.4 \\
\hline
\end{tabular}

parameter error. The smoothing error and retrieval noise are calculated from the a priori and measurement covariance matrices used in the retrieval (see Sect. 3). Since the photochemistry is fixed in our retrieval, the parameters having an impact on it should be taken into account in the estimation of the forward model parameter error. The number of forward model parameters is therefore significantly larger than in the case where the $\mathrm{BrO}$ diurnal variation is retrieved (as in Schofield et al., 2004 and 2006). The forward model parameter error $\mathbf{S}_{f}$ is calculated using the following expression (Rodgers, 2000):

$\mathbf{S}_{f}=\mathbf{G K}_{b} \mathbf{S}_{b} \mathbf{K}_{b}^{T} \mathbf{G}^{T}$

where $\mathbf{G}$ is the contribution functions or gain matrix, $\mathbf{K}_{b}$ is the sensitivity of the forward model to perturbations of forward model parameters $\mathbf{b}$, and $\mathbf{S}_{b}$ is the covariance matrix of b.
The forward model parameters $\mathbf{b}$, which are used to calculate $\mathbf{K}_{b}$, and their associated errors, which are used to derive $\mathbf{S}_{b}$, have been selected as in Preston et al. (1997) and are listed in Table 2. The relative change in most of the selected parameters correspond to their variability in March for the 2000-2004 period derived from the output of the stacked box photochemical model PSCBOX (see legend of Table 2 for details). This month has been chosen because most of the parameters influencing the $\mathrm{BrO}$ diurnal variation show their largest variability due to the fact that Harestua can be inside, outside or at the edge of the polar vortex.

The forward model parameter errors corresponding to the different parameters $\mathbf{b}$ on tropospheric and stratospheric $\mathrm{BrO}$ columns can be derived using the column operator $\mathbf{g}$ (Barret et al., 2003; Schofield et al., 2004). The matrix g sums over the relevant altitudes in the state vector to yield tropospheric and stratospheric columns. The covariance matrices 


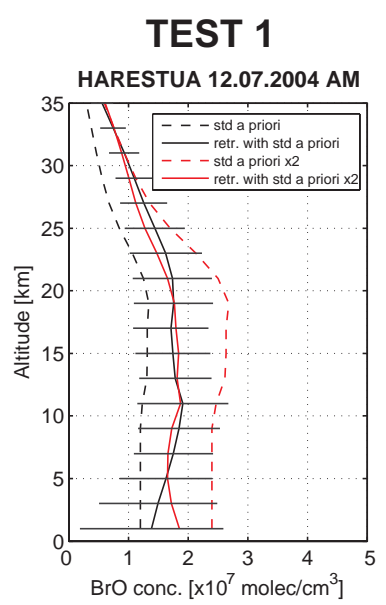

TEST 2

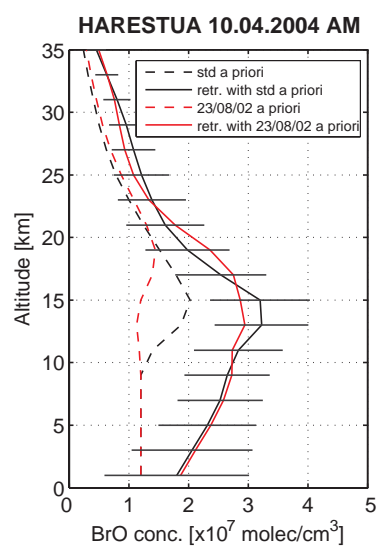

Fig. 6. Test of the impact of the a priori profile on the $\mathrm{BrO}$ retrievals. In test 1 (upper plot), the standard a priori profile is multiplied by a factor of 2. In the second test (lower plot), the standard a priori profile (output of the stacked box photochemical model PSCBOX for the 10 April 2004 at $56^{\circ} \mathrm{SZA} \mathrm{AM}$ ) peaking at $15 \mathrm{~km}$ altitude is replaced by a profile peaking at $19 \mathrm{~km}$ altitude (output of the photochemical model for the 23 August 2002 at $56^{\circ}$ SZA AM)

$\mathbf{S}_{f c}$ associated to the forward model parameter errors on the retrieved column quantities can be expressed as:

$\mathbf{S}_{f c}=\mathbf{g} \mathbf{S}_{f} \mathbf{g}^{T}$

The different contributions to the forward model parameter error averaged for the 2000-2006 period are given in Table 2. Total forward model parameter errors of 0.22 and $0.59 \times 10^{13} \mathrm{molec} / \mathrm{cm}^{2}$ are obtained for the tropospheric and stratospheric $\mathrm{BrO}$ columns, respectively, which correspond to about $20 \%$ of the columns retrieved at $80^{\circ} \mathrm{SZA}$ for the 2000-2006 period (see Sect. 6). The smoothing error and the retrieval noise on the retrieved columns have been calculated similarly using Eq. (7) and their mean values are presented in Table 3 as well as the total retrieval error. This table gives also the systematic errors related to the uncertainties on the $\mathrm{BrO}$ cross-sections and BrO RSCD. The first systematic er-

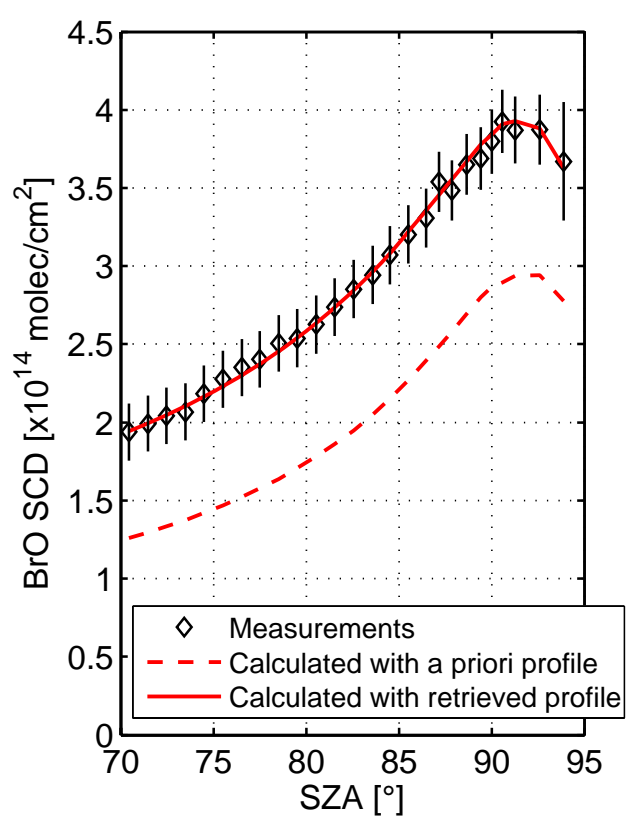

Fig. 7. Comparison between measured SCDs and those calculated using the a priori and retrieved profiles for the Harestua 24 March 2003 sunset retrieval. The error bars on the measurements correspond to 1-sigma standard deviation of the statistical error from the DOAS spectral fitting with in addition, some systematic components like the error associated to the uncertainties on the crosssections used in the DOAS analysis (main source of systematic biases)

ror is taken from Theys et al. (2007) while the second one is estimated from the error on BrO RSCD given in Table 1. The total retrieval error and the systematic errors are then added in quadrature in order to give the total errors on the retrieved tropospheric and stratospheric $\mathrm{BrO}$ columns, which rise to about 40 and $20 \%$, respectively.

\subsection{Retrieval fit results}

$\mathrm{BrO}$ retrievals are also quality-checked by comparing the measured SCDs to those calculated using the retrieved profiles. Figure 7 shows an example where the retrieval fit is in good agreement with the measurements. In practice, the selection of $\mathrm{BrO}$ retrievals is based on the residual of the retrieval fit: all the retrievals with a residual larger than a threshold value $\left(1 \times 10^{13} \mathrm{molec} / \mathrm{cm}^{2}\right)$ are rejected. This method of selection is roughly equivalent to a selection of clear-sky days based on the diurnal variation of $\mathrm{O}_{4}$. The measured BrO SCDs corresponding to the rejected retrievals display generally a strongly unsmoothed variation during twilight due to either a changing cloud cover or strong spectral interferences (e.g., $\mathrm{O}_{4}, \mathrm{NO}_{2}$, and Ring interferences). Retrieval residuals larger than the threshold value are often observed in fall and winter. There are several possible reasons to explain this feature: (1) The probability for having a 
changing cloud cover over Harestua is larger during this period. (2) Photochemical conditions can also change rapidly due to dynamical effects (Harestua is often close to or at the vortex edge) and therefore providing the $\mathrm{BrO}$ diurnal variation as an a priori information as in our profiling algorithm (see Sect. 3) could be a limitation and lead to high retrieval residuals. (3) During this period, the SZA range corresponding to the BrO SCD is smaller (SZA at local noon can reach $84^{\circ}$ at Harestua) and therefore the information content of the measurements is somewhat lower than during summer. For these reasons, we have decided to retrieve $\mathrm{BrO}$ profiles only from the ground-based DOAS measurements performed from mid-February to the end of October.

\section{Verification of the retrievals}

The consistency between our $\mathrm{BrO}$ profile retrievals and correlative data has been verified. For this purpose, the stratospheric part of the retrieved profiles is compared to SAOZ and LPMA/DOAS balloon profiles and the total $\mathrm{BrO}$ columns integrated from the retrieved profiles to GOME and SCIAMACHY nadir observations.

\subsection{Comparison to SAOZ and LPMA/DOAS balloon pro- files}

The SAOZ-BrO balloon experiment is designed for measuring BrO by solar occultation in the $320-400 \mathrm{~nm}$ spectral range during the afternoon ascent and from float at about $30 \mathrm{~km}$ (solar occultation). The spectral data are analyzed by the DOAS method and profile retrievals are performed using the onion peeling technique. The $\mathrm{BrO}$ fitting window is fixed to $332-370 \mathrm{~nm}$. More details on the instrument and the retrieval algorithm can be found in Pundt et al. (2002) and Dorf et al. (2006b).

As for the SAOZ balloon, the LPMA/DOAS balloon uses the solar occultation technique. The LPMA/DOAS payload consists of three spectrometers (two grating and one FT) enabling the analysis of direct sunlight from the UV to the mid-IR. The BrO DOAS evaluation is performed in the 346$360 \mathrm{~nm}$ wavelength range and vertical profiles are retrieved using the OEM. A detailed description of the LPMA/DOAS $\mathrm{BrO}$ measurements can be found in Harder et al. (1998 and 2000) and Dorf et al. (2006b).

For the present comparisons, all the SAOZ and DOAS balloon flights originated from Kiruna $\left(68^{\circ} \mathrm{N}, 21^{\circ} \mathrm{E}\right)$ in Sweden and only ascent data are taken into account. The selected flights are the following: 12 August 2002 and 16 March 2003 for SAOZ and 23 March 2003 and 24 March 2004 for LPMA/DOAS. It should be noted that for comparison in March, an examination of the potential vorticity (PV) maps at $475 \mathrm{~K}$ show that the Harestua and Kiruna stations are inside the polar vortex on 16 March 2003 and outside on 23 March 2003 and 24 March 2004. Ground-based BrO pro- files are retrieved at $87^{\circ}$ SZA (SAOZ 12 August 2002), $86^{\circ}$ SZA (SAOZ 16 March 2003), and 80 ${ }^{\circ}$ SZA (LPMA/DOAS 23 March 2003 and 24 March 2004). These SZA values are reached when the balloons are at an altitude of about $20 \mathrm{~km}$. Due to the variation of the SZA during the ascent of the balloon, a photochemical correction, calculated by using the photochemical model PSCBOX, is applied to the groundbased profiles in order to take into account this photochemical effect.

Since ground-based and balloon profiles have a significantly different vertical resolution (about $1 \mathrm{~km}$ and $8-10 \mathrm{~km}$ for balloon and ground-based profiles, respectively), the balloon profiles have to be degraded to the vertical resolution of the ground-based retrievals in order to allow direct comparison (Hendrick et al., 2004). This is done by convolving the balloon profiles with the ground-based averaging kernels using the following expression (Connor et al., 2004; Hendrick et al., 2004):

$\mathbf{x}_{s b}=\mathbf{x}_{a}+\mathbf{A}\left(\mathbf{x}_{b}-\mathbf{x}_{a}\right)$.

where $\mathbf{A}$ is the ground-based averaging kernel matrix, $\mathbf{x}_{a}$ is the a priori profile used in the ground-based retrieval, $\mathbf{x}_{b}$ is the balloon profile, and $\mathbf{x}_{s b}$ is the smoothed or convolved balloon profile and represents what the retrieval should produce assuming that $\mathbf{x}_{b}$ is the true profile and that the only source of error is the smoothing error.

The results of the comparisons between ground-based $\mathrm{BrO}$ retrievals and SAOZ and LPMA/DOAS balloon profiles are shown in Fig. 8. Concerning the comparisons with SAOZ balloon profiles, a good agreement is obtained on 16 March 2003 with a relative difference smaller than $12 \%$ over the entire $10-28 \mathrm{~km}$ altitude range. For the 12 August 2002 case, the ground-based retrieval overestimates the $\mathrm{SAOZ}$ profile in the $17-29 \mathrm{~km}$ altitude range, with a maximum relative difference value of $35 \%$ obtained around $25 \mathrm{~km}$ altitude. However, the observed differences are within the error bars of the ground-based profile. Concerning the comparison with the LPMA/DOAS balloon profile on 23 March 2003, an underestimation of about $20 \%$ by the ground-based retrieval occurs between 8 and $15 \mathrm{~km}$ altitude, both profiles differing by less than $10 \%$ (in absolute value) above $18 \mathrm{~km}$. In case of the 24 March 2004 comparison, the ground-based $\mathrm{BrO}$ retrieval systematically overestimates the LPMA/DOAS profile in the entire 8-32 $\mathrm{km}$ altitude range, with relative difference values between 7 and $21 \%$ in the $8-21 \mathrm{~km}$ altitude range and between 21 and $37 \%$ above $21 \mathrm{~km}$. However, the observed differences are again within the error bars of the ground-based profile.

The 11-28 km BrO partial column amounts calculated by integrating the ground-based and smoothed SAOZ and LPMA/DOAS balloon profiles have been also compared. The partial column amounts and relative differences are presented in Table 4 . The comparison gives a satisfying agreement, with partial column values differing respectively by $+17 \%$ (SAOZ 12 August 2002), -4\% (SAOZ 16 March 
Table 4. 11-28 km BrO partial column values calculated from ground-based UV-visible BrO profiles retrieved at Harestua and smoothed SAOZ and LPMA/DOAS balloon profiles. Both SAOZ and LPMA/DOAS balloons were launched from Kiruna in Sweden. The relative differences in $\%$ appear in the third row.

\begin{tabular}{lllll}
\hline & \multicolumn{2}{c}{ SAOZ balloon } & \multicolumn{2}{c}{ LPMA/DOAS balloon } \\
& 12 Aug 2002 & 16 Mar 2003 & 24 Mar 2003 & 24 Mar 2004 \\
\hline $\begin{array}{l}\text { (a) GB UV-visible } \\
\left(\times 10^{13} \text { molec/cm }{ }^{2}\right)\end{array}$ & 1.4 & 2.6 & 2.8 & 3.3 \\
$\left.\begin{array}{l}\text { (b) Smoothed balloon } \\
\left(\times 10^{13} \text { molec/cm }\right.\end{array}\right)$ & 1.2 & 2.7 & 3.1 & 2.9 \\
\begin{tabular}{l}
$(\mathrm{a}-\mathrm{b}) / \mathrm{b} \times 100(\%)$ \\
\hline
\end{tabular} & +17 & -4 & -10 & +14 \\
\hline
\end{tabular}

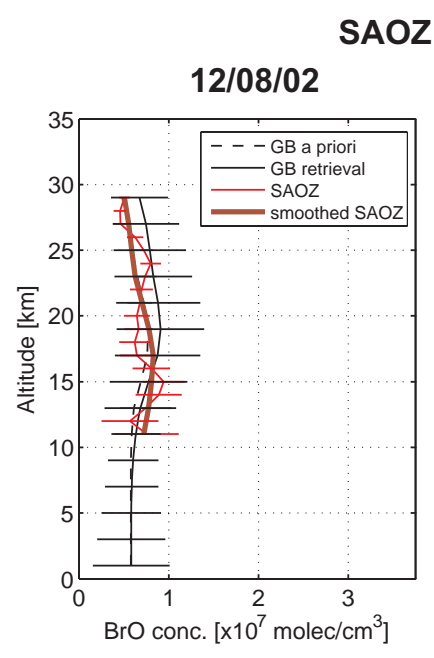

SAOZ BALLOON
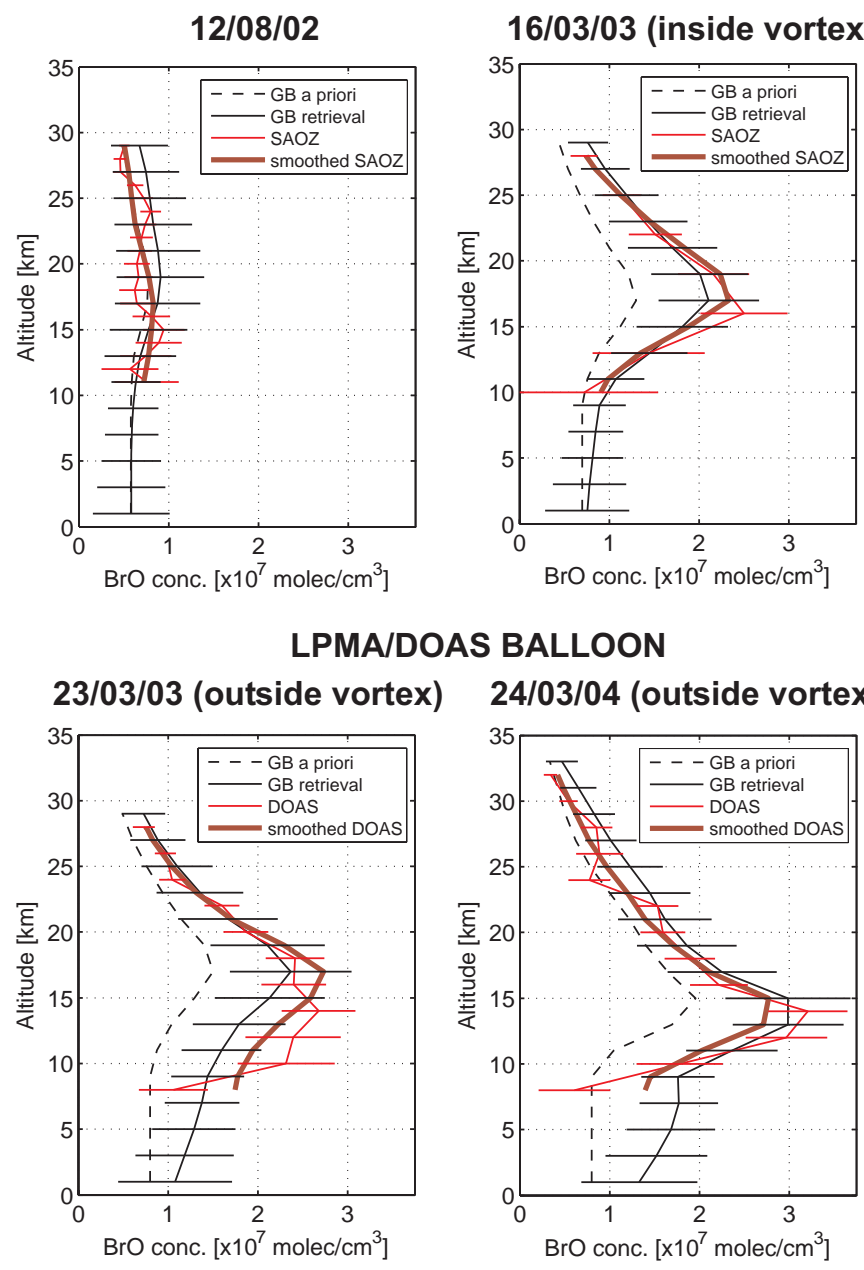

\section{x)}
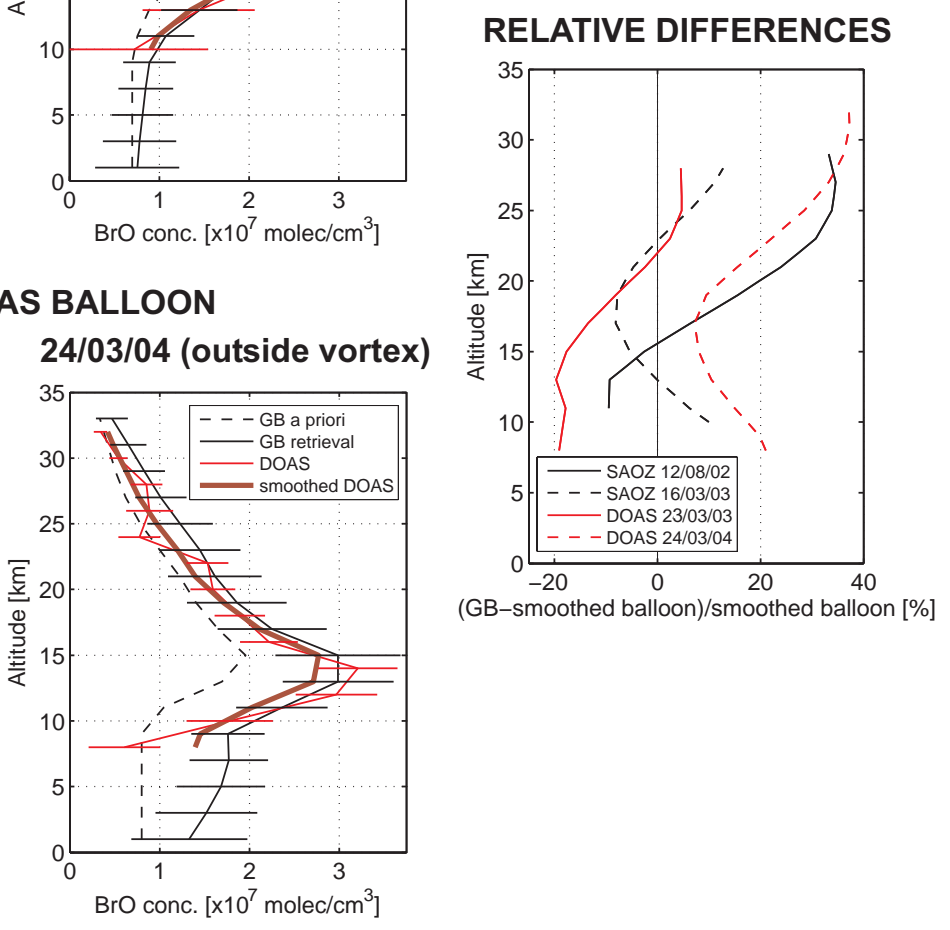

Fig. 8. Comparison between ground-based UV-visible BrO profiles at Harestua and SAOZ and LPMA/DOAS ascent balloon BrO profiles. All balloon flights originated from Kiruna, Sweden. For direct comparison, balloon profiles have been smoothed by convolving them with the ground-based UV-visible averaging kernels. The relative differences between ground-based retrievals and smoothed balloon profiles appear in the right plot.

2003), $-10 \%$ (LPMA/DOAS 23 March 2003), and $+14 \%$ (LPMA/DOAS 24 March 2004). The overall conclusion of these comparisons (profiles and partial columns) is that the stratospheric part of the ground-based $\mathrm{BrO}$ profiles shows a good consistency with SAOZ and LPMA/DOAS balloon profiles. 
5.2 Comparison to GOME and SCIAMACHY nadir observations

GOME (Global Ozone Monitoring Experiment) is a nadirviewing spectrometer that measures solar radiation backscattered from the atmosphere in the $240-790 \mathrm{~nm}$ wavelength range (Burrows et al., 1999). The instrument, aboard the ESA/ERS-2 satellite launched in April 1995, flies in a sun-synchronous orbit at an altitude of $780 \mathrm{~km}$ with a local crossing time at the Equator of about 10:30 LT. The measured nadir radiances are analysed using the DOAS technique. The GOME BrO data used for the verification of the ground-based $\mathrm{BrO}$ retrievals are the total columns retrieved by the scientific ("non-operational") spectral inversion algorithm developed at IASB-BIRA. The DOAS settings follow the recommendations of Aliwell et al. (2002) including a wavelength range from 345 to $359 \mathrm{~nm}$ and $\mathrm{BrO}$ absorption cross-sections from Wilmouth et al. (1999). A detailed description of the inversion algorithm and DOAS settings can be found in Van Roozendael et al. (1999) and at the following web page: http://www.oma.be/BIRA-IASB/Molecules/BrO/ Documents/BIRA_SCIA_BrO_ADD_v1r1.pdf.

SCIAMACHY (SCanning Imaging Absorption spectroMeter for Atmospheric CHartographY) is the successor of GOME and was launched in March 2002 aboard the ESA/ENVISAT platform. As for ERS-2, ENVISAT flies in a sun-synchronous orbit and the local crossing time at the Equator is about 10:00 LT. The SCIAMACHY imaging spectrometer measures the solar radiation transmitted, back-scattered and reflected from the atmosphere in the 240$2400 \mathrm{~nm}$ wavelength range and in three different viewing geometries: nadir, limb, and sun/moon occultations, which yield total column values as well as vertical profiles. As for GOME, the nadir radiances are analysed using the scientific DOAS algorithm developed at IASB-BIRA. The settings are similar to those used for GOME except the wavelength range which is now $336-347 \mathrm{~nm}$. The main reason for this is the presence of a strong anomaly of the polarization response of the SCIAMACHY instrument centered in the middle of the wavelength interval used for $\mathrm{BrO}$ retrieval from GOME (346-359 nm). Due to this change in the BrO fitting window, the $\mathrm{BrO}$ absorption cross-sections set is taken here from Wahner et al. (1988). Because reliable SCIAMACHY solar spectra were unavailable during the first year of measurements, an earthshine radiance selected daily around Equator is used as control spectrum for the BrO slant column retrieval. The corresponding equatorial offset is assumed to be $7.5 \times 10^{13} \mathrm{molec} / \mathrm{cm}^{2}$, which is in good consistency with test $\mathrm{BrO}$ retrievals made around the Equator using daily sun reference spectra (see also Theys et al., 2007). More details on the IASB-BIRA SCIAMACHY total BrO columns can be found at http://www.oma.be/BIRA-IASB/Molecules/ BrO/Documents/BIRA_SCIA_BrO_ADD_v1r1.pdf.

Air mass factors (AMFs) are needed to convert the GOME and SCIAMACHY nadir BrO slant column densities, which

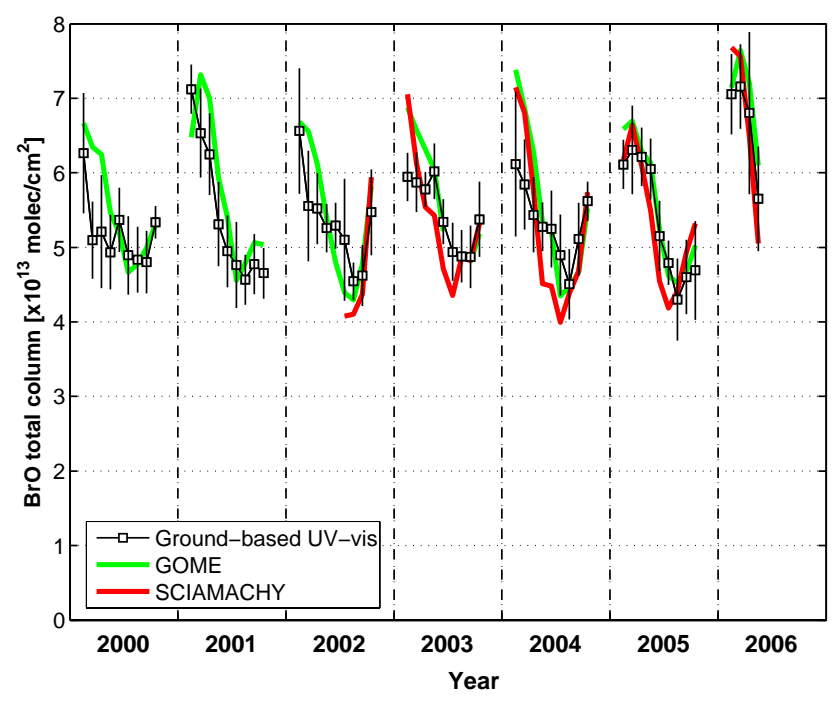

Fig. 9. Comparison between ground-based UV-vis, GOME, and SCIAMACHY nadir total BrO columns (monthly means). Groundbased VCDs have been calculated by integrating the retrieved $\mathrm{BrO}$ profiles. The error bars on the ground-based BrO VCDs correspond to the $\mathrm{BrO}$ VCDs natural variability (1-sigma standard deviation).

are the direct product of the DOAS analysis, into vertical columns. AMFs are calculated using the UVspec/DISORT RTM accounting for the SZA as well as the line-of-sight angle of the GOME and SCIAMACHY nadir observations. The ground-based $\mathrm{BrO}$ profiles retrieved at the SZA corresponding to the satellites overpass time (about 10:30 LT) are also provided as input to the RTM in order to properly take into account the tropospheric contribution to the total $\mathrm{BrO}$ columns in the AMF calculation.

Monthly means of ground-based UV-visible, GOME, and SCIAMACHY nadir total BrO columns for the 2000-2006 period are presented in Fig. 9. Mean GOME and SCIAMACHY BrO column amounts are calculated using all pixels falling within a radius of $200 \mathrm{~km}$ around Harestua. Groundbased UV-visible retrievals show good consistency with both satellite measurements in terms of seasonal variation and inter-annual variability. More quantitatively, a good agreement is observed between ground-based and GOME total $\mathrm{BrO}$ columns with a relative difference generally below $15 \%$ (in absolute values), the largest discrepancy being obtained in spring 2000 with ground-based columns $20 \%$ smaller than those from GOME. A similar agreement is observed with SCIAMACHY nadir columns except in summer where SCIAMACHY tends to give systematically lower column values than both ground-based and GOME data.

\section{Tropospheric and stratospheric BrO columns}

Tropospheric and stratospheric $\mathrm{BrO}$ columns are calculated by integrating the retrieved profiles in the appropriate altitude 
Table 5. Mean tropospheric column values at $80^{\circ} \mathrm{SZA}$ obtained for late winter/early spring (15 February-30 April), late spring/summer (1 May-15 August), and late summer/early fall (16 August-15 October) conditions during the 2000-2006 period. Mean columns and their corresponding 1-sigma standard deviation (values given between brackets) are in units of $\times 10^{13} \mathrm{molec} / \mathrm{cm}^{2}$ and pptv. Values in italic are the number of measurement days taken into account for the calculation of the mean.

\begin{tabular}{|c|c|c|c|c|c|c|}
\hline & \multicolumn{6}{|c|}{ Tropospheric BrO column } \\
\hline & \multicolumn{2}{|c|}{$15 / 02 \rightarrow 30 / 04$} & \multicolumn{2}{|c|}{$01 / 05 \rightarrow 15 / 08$} & \multicolumn{2}{|c|}{$16 / 08 \rightarrow 15 / 10$} \\
\hline & $\left(\times 10^{13} \mathrm{molec} / \mathrm{cm}^{2}\right)$ & (pptv) & $\left(\times 10^{13} \mathrm{molec} / \mathrm{cm}^{2}\right)$ & (pptv) & $\left(\times 10^{13} \mathrm{molec} / \mathrm{cm}^{2}\right)$ & (pptv) \\
\hline \multirow[t]{2}{*}{$80^{\circ} \mathrm{SZA}$ am } & $1.72(0.60)$ & $1.1(0.4)$ & $0.92(0.32)$ & $0.6(0.2)$ & $1.05(0.38)$ & $0.7(0.2)$ \\
\hline & & 208 days) & & (322 days) & & (138 days) \\
\hline \multirow[t]{2}{*}{$80^{\circ} \mathrm{SZA} \mathrm{pm}$} & $1.41(0.42)$ & $0.9(0.3)$ & $0.93(0.31)$ & $0.6(0.2)$ & $1.01(0.37)$ & $0.6(0.2)$ \\
\hline & & 393 days) & & (391 days) & & (225 days) \\
\hline $\begin{array}{l}80^{\circ} \mathrm{SZA} \\
\mathrm{am} \& \mathrm{pm}\end{array}$ & $1.52(0.51)$ & $1.0(0.3)$ & $0.92(0.31)$ & $0.6(0.2)$ & $1.03(0.37)$ & $0.6(0.2)$ \\
\hline
\end{tabular}
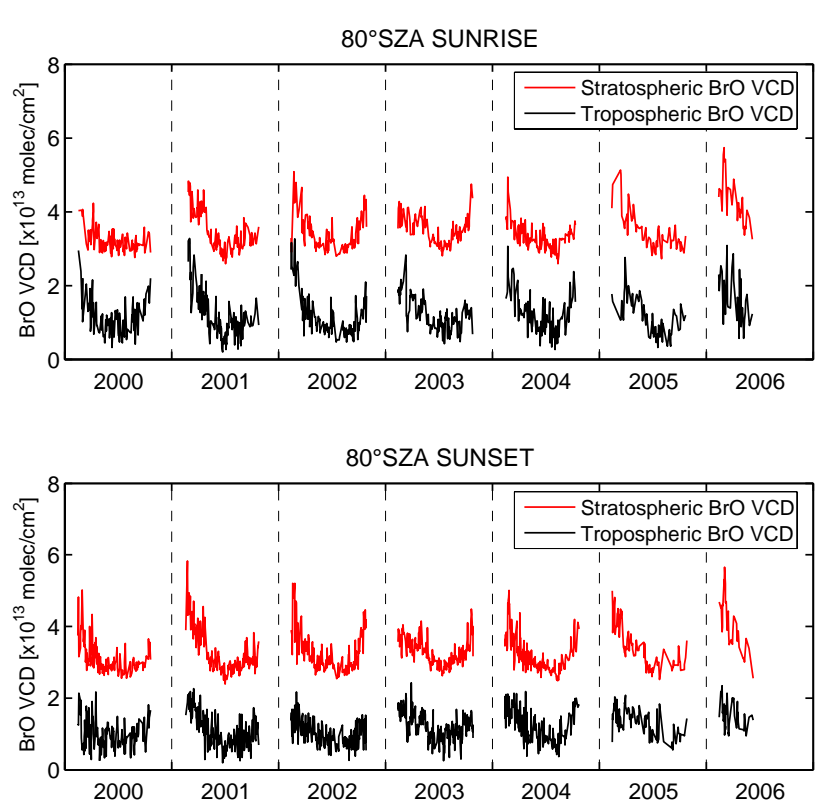

Fig. 10. Stratospheric and tropospheric BrO columns calculated from profiles retrieved at $80^{\circ} \mathrm{SZA}$ sunrise (upper plot) and sunset (lower plot) for the 2000-2006 period.

ranges. For each day, the tropopause height is estimated using NCEP pressure and temperature profiles and by adopting the WMO definition of the tropopause: height of the base of a layer at least $2 \mathrm{~km}$ thick, in which the rate of decrease of temperature with height is less than $2 \mathrm{~K} / \mathrm{km}$.

Tropospheric and stratospheric BrO columns corresponding to $80^{\circ}$ SZA sunrise and sunset for the 2000-2006 period are shown in Fig. 10. Both tropospheric and stratospheric columns display a marked seasonality with larger column values in late winter/early spring and fall than in summer (U-shape). Tropospheric BrO columns averaged for late winter/early spring ( 15 February-30 April), late spring/summer (1 May-15 August), and late summer/early fall (16 August-15 October) conditions are presented in Table 5 . In late winter/early spring, the mean tropospheric $\mathrm{BrO}$ column is slightly larger at sunrise than at sunset with values of $1.72 \pm 0.60$ and $1.41 \pm 0.42 \times 10^{13} \mathrm{molec} / \mathrm{cm}^{2}$, respectively. Assuming that $\mathrm{BrO}$ is uniformly mixed in the troposphere, these column values correspond to volume mixing ratios of $1.1 \pm 0.4$ and $0.9 \pm 0.3$ pptv, respectively. The errors on the columns given here correspond to their natural variability (1-sigma standard deviation) but it should be noted that the error budget described in Sect. 4.2 gives slightly larger error values ( $\sim 40 \%$ of the tropospheric columns).Smaller column amounts are obtained in both late spring/summer and late summer/early fall, with values of about $0.92 \pm 0.31$ and $1.03 \pm 0.37 \times 10^{13} \mathrm{molec} / \mathrm{cm}^{2}$, respectively (both corresponding to a $\mathrm{BrO}$ volume mixing ratio of $0.6 \pm 0.2 \mathrm{pptv}$ ). For these periods, column amounts are similar at sunrise and sunset.

Our estimates of the tropospheric $\mathrm{BrO}$ column amount show a good consistency with previously published studies. Harder et al. (1998 and 2000), Richter et al. (2002) and Van Roozendael et al. (2002) found that $\mathrm{BrO}$ measurements from the GOME satellite instrument are consistent with a tropospheric $\mathrm{BrO}$ column ranging from 1 to $4 \times 10^{13} \mathrm{molec} / \mathrm{cm}^{2}$. Using the GOME successor SCIAMACHY, Sinnhuber et al. (2005) have suggested that the average global tropospheric $\mathrm{BrO}$ column below $15 \mathrm{~km}$ altitude is about $2-4 \times 10^{13} \mathrm{molec} / \mathrm{cm}^{2}$. Balloon DOAS measurements performed by Fitzenberger et al. (2000) revealed that the tropospheric $\mathrm{BrO}$ amount could range from 0.6 to $3.7 \times 10^{13} \mathrm{molec} / \mathrm{cm}^{2}$. Tropospheric BrO columns have been also estimated using ground-based DOAS observations. Schofield et al. (2004 and 2006) found "background" tropospheric column values lower than the other estimates (about $0.2-0.3 \times 10^{13} \mathrm{molec} / \mathrm{cm}^{2}$ ) using combined zenith-sky and direct sun DOAS measurements in Lauder $\left(45^{\circ} \mathrm{S}\right)$ and $\mathrm{Ar}-$ rival Heights $\left(78^{\circ} \mathrm{S}\right)$. In contrast, Theys et al. (2007) inferred tropospheric $\mathrm{BrO}$ columns of about $1.1 \times 10^{13} \mathrm{molec} / \mathrm{cm}^{2}$ from ground-based MAX-DOAS measurements in Reunion Island $\left(21^{\circ} \mathrm{S}\right)$, consistent with the abovementioned satellite 
and balloon estimates and with our tropospheric columns retrieved at Harestua in late spring/summer. Also from groundbased MAX-DOAS measurements in the tropics (Nairobi, $1^{\circ} \mathrm{S}$ ), Fietkau et al. (2007) have derived slightly lower tropospheric BrO column amounts, in the range of $0.4-0.75 \times 10^{13}$ molec $/ \mathrm{cm}^{2}$.

\section{Comparison to model calculations}

Stratospheric and tropospheric $\mathrm{BrO}$ columns calculated from profiles retrieved at the GOME overpass time ( 10:30 LT) are compared to the SLIMCAT stratospheric and $p$ TOMCAT tropospheric chemical transport models (CTMs), respectively. At Harestua, 10:30 LT corresponds to about $74^{\circ}$ SZA in mid-February and $39^{\circ}$ SZA in mid-June. It should be noted that the choice of the GOME overpass time for the comparison (and not $80^{\circ} \mathrm{SZA}$ as in Sect. 6) allows us to avoid having to interpolate through the output values of the tropospheric CTM (see below).

The $p$-TOMCAT (parallel-Tropospheric Off-Line Model of Chemistry and Transport) model is an off-line threedimensional tropospheric CTM with a detailed bromine chemistry scheme that contains gas-phase reactions and heterogeneous reactions on cloud particles and aerosols. It includes bromine emissions from sea salt and bromocarbon photo-oxidation as well as bromine removal from dry and wet deposition (see Yang et al., 2005 for a detailed description of this version of $p$-TOMCAT). For the present study, the model was run for the years 2002 and 2003 at a horizontal spatial resolution of $5.6^{\circ} \times 5.6^{\circ}$ on 31 levels from the surface up to $10 \mathrm{hPa}$ using winds and temperature derived from the ECMWF (European Centre for Medium-Range Weather Forecasts) operational analysis. The output frequency is fixed to $2 \mathrm{~h}$ from 00:00 UT and the model output at 10:00 UT ( $\sim 10: 45 \mathrm{LT})$ is used for the comparison. The tropospheric $\mathrm{BrO}$ column amounts are linearly interpolated from the closest model grids to Harestua, centered at $63.68^{\circ} \mathrm{N}, 11.25^{\circ} \mathrm{E}$ and $58.14^{\circ} \mathrm{N}, 11.25^{\circ} \mathrm{E}$. Concerning bromine emission from sea salt, the scenario used for sea-salt production is called SMI and involves particles with dry radii between 0.1 and $10 \mu \mathrm{m}$ (Yang et al., 2005). Two different model runs are considered in our study: run 1 (standard run) and run 2 which includes the $\mathrm{HBr}+\mathrm{HOBr}$ reaction on aerosols since this reaction can be important in the troposphere and may increase the $\mathrm{BrO}$ level. It should be noted that the current version of the $p$-TOMCAT model does not include bromine emission from sea-ice (snowpack and frost flowers), which is likely to be an important bromine source in the polar region (e.g., Kaleschke et al., 2004; Simpson et al., 2005).

For the stratosphere, we use the SLIMCAT 3D-CTM (Chipperfield, 1999 and 2006), and more particularly run D from this model (Feng et al., 2007). In this run, the CTM was integrated with a horizontal resolution of $7.5^{\circ} \times 7.5^{\circ}$ on 24 levels from the surface to about $55 \mathrm{~km}$ altitude. The
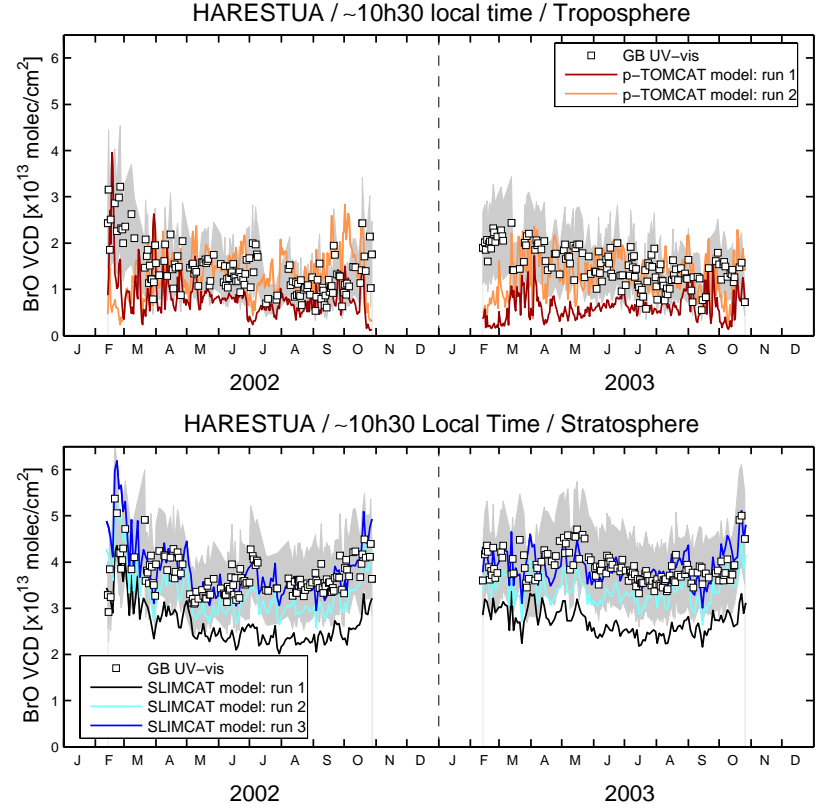

Fig. 11. Comparison between ground-based UV-visible and modeled tropospheric and stratospheric BrO columns for the 2002-2003 period. Tropospheric and stratospheric BrO columns are simulated using the p-TOMCAT and SLIMCAT 3D CTMs, respectively. In case of the p-TOMCAT model, two runs are considered: run 1 with SMI scenario for sea-salt production; run 2 with the same SMI scenario but including the $\mathrm{HOBr}+\mathrm{HBr}$ reaction on aerosols. In the SLIMCAT model case, three runs are considered: run 1 (standard run), and runs 2 and 3 with respectively 6 and 8 pptv accounting for VSLS and added directly to the SLIMCAT long-lived bromine source gases profile (see Fig. 12 for a plot of the different Bry profiles). The grey-shaded area indicates the error on the ground-based columns.

model was forced using ECMWF analyses and the simulation started on 1 January 1977 . The halogen loading was specified from observed tropospheric $\mathrm{CH}_{3} \mathrm{Br}$ and halons (WMO, 2003) with an additional 6 pptv contribution from very short-lived species (VSLS), added by an empirical scaling of $\mathrm{CH}_{3} \mathrm{Br}$. Accordingly, the total stratospheric bromine loading around 2002 is $21.2 \mathrm{pptv}$. Output was saved at 00:00 UT every two days and linearly interpolated at the location of Harestua. This output served as input to our stacked box photochemical model PSCBOX in order to calculate the stratospheric $\mathrm{BrO}$ profile corresponding to 10:30 LT.

The comparison between ground-based and modeled $\mathrm{BrO}$ columns is presented in Fig. 11 for the 2002-2003 period. Concerning the stratosphere, the model run used significantly underestimates (by maximum 30\%) the ground-based UVvisible columns. This feature can be partly explained by the fact that in this model run, $\mathrm{CH}_{3} \mathrm{Br}$ is scaled in order to represent all bromine source gases, including short-lived sources. Since these source gases are decomposed faster than methyl bromide, this can lead to an underestimation of the 


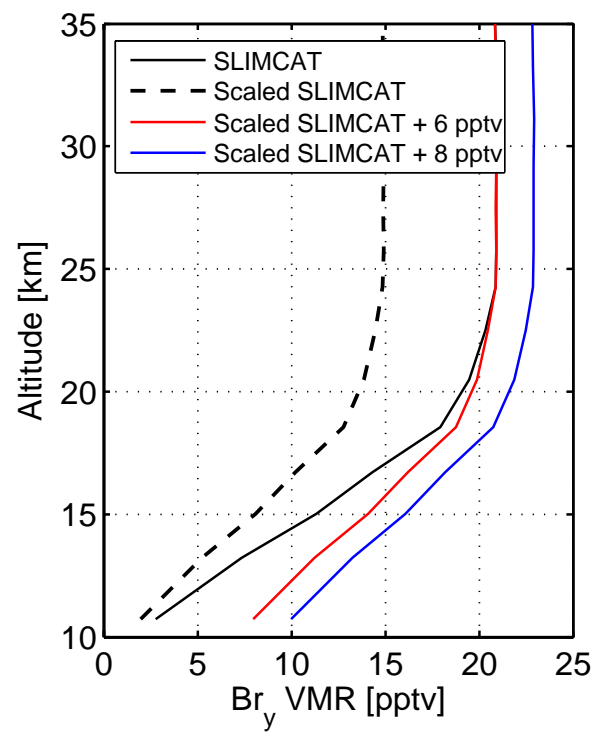

Fig. 12. Bry $_{\mathrm{y}}$ profiles used in the comparison between the groundbased stratospheric BrO column amounts and the SLIMCAT model.

$\mathrm{Br}_{\mathrm{y}}$ volume mixing ratio in the lower stratosphere and therefore of the integrated $\mathrm{BrO}$ vertical column. As in Theys et al. (2007), this effect is investigated by considering the case where the short-lived species are totally converted to $\mathrm{Br}_{\mathrm{y}}$ at the tropopause. In order to achieve that, we have applied an offset of 6 and 8 pptv directly to the SLIMCAT Br $_{y}$ profile scaled by the ratio between the contribution of long-lived bromine sources (15 pptv) and the total bromine loading assumed in SLIMCAT (21.2 pptv). The different $\mathrm{Br}_{\mathrm{y}}$ profiles are plotted in Fig. 12. We see from Fig. 11 that with a contribution of 6 pptv from VSLS, modeled columns are within the error bars associated to the ground-based columns but still underestimate them. A good quantitative agreement is obtained when a contribution of 8 pptv from VSLS is assumed in the model. These results are in good consistency with previous studies (Pfeilsticker et al., 2000; Salawitch, 2005; Dorf et al., 2006a). This also confirms the findings of Feng et al. (2007), who have tested different methods of implementing the bromine source gases in the SLIMCAT model and found that the agreement between model and balloon data is significantly improved when accounting explicitly for the short-lived source gases.

Concerning the troposphere, run 1 of the $p$-TOMCAT model systematically underestimates the ground-based $\mathrm{BrO}$ columns (with differences sometimes larger than 50\%). Using run 2 (also with SMI scenario for sea-salt production but including $\mathrm{HOBr}+\mathrm{HBr}$ reaction on aerosols), the agreement is greatly improved except in February and March where a significant underestimation by the model still persists. The non-inclusion in the current version of the model of bromine emissions from frost flowers and snowpack might possibly explain this feature since during this period, air masses with enhanced $\mathrm{BrO}$ concentration due to bromine explosion events could be transported from the polar region to Harestua. Finally, Fig. 11 also shows that the $p$-TOMCAT model reproduces reasonably well some of the short-term variations in the ground-based $\mathrm{BrO}$ columns, especially in 2003.

\section{Conclusions}

$\mathrm{BrO}$ vertical profiles have been retrieved using ground-based zenith-sky DOAS observations performed at the NDACC station of Harestua $\left(60^{\circ} \mathrm{N}, 11^{\circ} \mathrm{E}\right)$ during the 2000-2006 period. The sensitivity to the tropospheric detection of $\mathrm{Br}_{\mathrm{O}}$ by zenith-sky UV-visible observations has been increased by choosing for each year a fixed noon summer reference spectrum for the DOAS analysis. The consistency between our $\mathrm{Br}_{\mathrm{O}}$ profile retrievals and correlative data have been verified and a good agreement has been obtained with SAOZ and LPMA/DOAS balloon profiles (stratospheric part of the retrieved profiles) and with GOME and SCIAMACHY nadir observations (total columns integrated from the retrieved profiles). The error budget and the information content related to the retrievals have been also carefully characterized and the impact of the a priori profile on the retrievals has been investigated.

Tropospheric $\mathrm{Br}_{\mathrm{O}}$ column amounts integrated from the profiles retrieved at $80^{\circ} \mathrm{SZA}$ and averaged for the 2000 2006 period range from $1.52 \pm 0.62 \times 10^{13} \mathrm{molec} / \mathrm{cm}^{2}$ in late winter/early spring to $0.92 \pm 0.38 \times 10^{13} \mathrm{molec} / \mathrm{cm}^{2}$ in summer. Assuming that $\mathrm{Br} O$ is uniformly mixed in the troposphere, these values correspond to $1.0 \pm 0.4$ and $0.6 \pm 0.2 \mathrm{pptv}$, respectively, and are consistent with previously published estimates inferred from balloon, satellite, and ground-based UV-vis observations. Daytime (10:30 LT) tropospheric and stratospheric $\mathrm{BrO}$ columns have been also compared to the $p$-TOMCAT and SLIMCAT 3-D CTMs for the 2002-2003 period. In case of the $p$-TOMCAT model, two different runs have been considered: run 1 with SMI scenario for sea-salt production and run 2 with the same SMI scenario but including the $\mathrm{HOBr}+\mathrm{HBr}$ reaction on aerosols. Run 1 systematically underestimates the observations while run 2 shows a good quantitative agreement with the ground-based tropospheric columns and reproduces well some of their shortterm variations, especially in 2003. However, a systematic underestimation is obtained in February-March. The non-inclusion in the current version of $p$-TOMCAT of frost flowers and snowpack as bromine sources could explain this finding. In the stratosphere, the retrieved ground-based $\mathrm{Br}_{\mathrm{O}}$ columns have been compared to the SLIMCAT model. The model run used significantly underestimates the retrieved $\mathrm{Br}_{\mathrm{O}}$ columns. This finding can be partly explained by the fact that in this model run, $\mathrm{CH}_{3} \mathrm{Br}$ is scaled in order to represent all bromine source gases, including short-lived sources. Since these source gases are decomposed faster than methyl 
bromide, this can lead to an underestimation of the $\mathrm{Br}_{\mathrm{y}}$ volume mixing ratio in the lower stratosphere and therefore of the integrated $\mathrm{BrO}$ vertical column. We have shown that a good quantitative agreement can be obtained if 6 to 8 pptv, accounting for very short-lived bromine species, are added directly to the SLIMCAT long-lived bromine source gases profile, which is equivalent to assume that the short-lived species are totally converted to $\mathrm{Br}_{\mathrm{y}}$ at the tropopause. This contribution of 6 to 8 pptv from VSLS to the total bromine loading is consistent with recently published studies (e.g., WMO 2007).

Acknowledgements. This research was financially supported by the Belgian Prodex $\mathrm{NO}_{\mathrm{y}}-\mathrm{Br}_{\mathrm{y}}$.

Edited by: R. von Glasow

\section{References}

Aliwell, S. R., Van Roozendael, M., Johnston, P. V., Richter, A., Wagner, T., Arlander, D. W., Burrows, J. P., Fish, D. J., Jones, R. L., Tørnkvist, K. K., Lambert, J.-C., Pfeilsticker, K., and Pundt, I.: Analysis for $\mathrm{Br}_{\mathrm{O}}$ in zenith-sky spectra: An intercomparison exercise for analysis improvement, J. Geophys. Res., 107(D14), 4199, doi:10.1029/2001JD000329, 2002.

Barret, B., De Mazière, M., and Mahieu, E.: Ground-based FTIR measurements of $\mathrm{CO}$ from the Jungfraujoch : characterisation and comparison with in situ surface and MOPITT data, Atmos. Chem. Phys., 3, 2217-2223, 2003,

http://www.atmos-chem-phys.net/3/2217/2003/.

Bobrowski, N., Hönninger, G., Galle, B., and Platt, U.: Detection of bromine monoxide in a volcanic plume, Nature, 423, 273-276, 2003.

Brewer, A. W., McElroy, C. T., and Kerr, J. B.: Nitrogen dioxide concentration in the atmosphere, Nature, 246, 129-133, 1973.

Burrows, J. P., Weber, M., Buchwitz, M., Rozanov, V.V., Ladstädter-Weissenmayer, A., Richter, A., de Beek, R., Hoogen, R., Bramstedt, K., Eichmann, K.-U., Eisinger, M., and Perner, D.: The Global Ozone Monitoring Experiment (GOME): Mission concept and first scientific results, J. Atm. Sci., 56, 151-175, 1999.

Chipperfield, M. P. and Pyle, J. A.: Model sensitivity studies of arctic ozone depletion, J. Geophys. Res., 103(D21), 28 389-28 403, 1998.

Chipperfield, M. P.: Multiannual simulations with a threedimensional chemical transport model, J. Geophys. Res., 104(D1), 1781-1805, 1999.

Chipperfield, M. P.: New version of the TOMCAT/SLIMCAT offline chemical transport model: Intercomparison of stratospheric tracer experiments, Q. J. R. Meteorol. Soc., 132, 1179-1203, doi:10.1256/qj.05.51, 2006.

Connor, B. J., Siskind, D. E., Tsou, J. J., Parrish, A., and Remsberg, E. E.: Ground-based microwave observations of ozone in the upper stratosphere and mesosphere, J. Geophys. Res., 99(D8), 16757-16770, 1994.

Denis, L., Roscoe, H. K., Chipperfield, M. P., Van Roozendael, M., and Goutail, F.: A new software for $\mathrm{NO}_{2}$ vertical profile retrieval from ground-based zenith-sky spectrometers, J. Quant. Spectrosc. Radiat. Transfer, 92, 321-333, 2005.

Dorf, M., Butler, J. H., Butz, A., Camy-Peyret, C., Chipperfield, M. P., Kritten, L., Montzka, S. A., Simmes, B., Weidner, F., and Pfeilsticker, K.: Observations of long-term trend in stratospheric bromine reveal slow down in growth, Geophys. Res, Lett., 33, L24803, doi:10.1029/2006GL027714, 2006a.

Dorf, M., Bösch, H., Butz, A., Camy-Peyret, C., Chipperfield, M. P., Goutail, F., Grunow, K., Hendrick, F., Hrechanyy, S., Naujokat, B., Pommereau, J.-P., Van Roozendael, M., Sioris, C., Stroh, F., Weidner, F., and Pfeilsticker, K.: Balloonborne stratospheric $\mathrm{BrO}$ measurements: Comparison with Envisat/SCIAMACHY BrO limb profiles, Atmos. Chem. Phys., 6, 2483-2501, 2006b.

Errera, Q. and Fonteyn, D.: Four-dimensional variational chemical assimilation of CRISTA stratospheric measurements, J. Geophys. Res., 106(D11), 12 253-12 265, 2001.

Feng, W., Chipperfield, M. P., Dorf, M., and Pfeilsticker, K., Midlatitude ozone changes: studies with a 3-D CTM forced by ERA40 analyses, Atmos. Chem. Phys., 7, 2357-2369, 2007, http://www.atmos-chem-phys.net/7/2357/2007/.

Fietkau, S., Medeke, T., Richter, A., Sheode, N., Sinnhuber, B.-M., Wittrock, F., Theys, N., Van Roozendael, M., and Burrows, J. P.: Ground-based measurements of tropospheric and stratospheric Bromine monoxide above Nairobi $\left(1^{\circ} \mathrm{S}, 36^{\circ} \mathrm{E}\right)$, Atmos. Chem. Phys. Discuss., 7, 6527-6555, 2007, http://www.atmos-chem-phys-discuss.net/7/6527/2007/.

Fitzenberger, R., Bösch, H., Camy-Peyret, C., Chipperfield, M.P., Harder, H., Platt, U., Sinnhuber, B.-M., Wagner, T., and Pfeilsticker, K.: First profile measurements of tropospheric BrO, Geophys. Res. Lett., 27, 2921-2924, 2000.

Frieß, U., Hoowedel, J., König-Langlo, G., Wagner, T., and Platt, U., Dynamics and chemistry of tropospheric bromine explosion events in the Antarctic coastal region, J. Geophys. Res., 109, D06305, doi:10.1029/2003JD004133, 2004.

Frieß, U., Monks, P. S., Remedios, J. J., Rozanov, A., Sinreich, R., Wagner, T., and Platt, U.: MAX-DOAS $\mathrm{O}_{4}$ measurements: A new technique to derive information on atmospheric aerosols: 2. Modeling studies, J. Geophys. Res., 111, D14203, doi:10.1029/2005JD006618, 2006.

Harder, H., Camy-Peyret, C., Ferlemann, F., Fitzenberger, R., Hawat, T., Osterkamp, H., Perner, D., Platt, U., Schneider, M., Vradelis, P., and Pfeilsticker, K.: Stratospheric BrO profiles measured at different latitudes and seasons: Atmospheric observations, Geophys. Res. Lett., 25, 3843-3846, 1998.

Harder, H., Bösch, H., Camy-Peyret, C., Chipperfield, M., Fitzenberger, R., Payan, S., Perner, D., Platt, U., Sinnhuber, B.-M., and Pfeilsticker, K.: Comparison of measured and modeled stratospheric BrO: Implications for the total amount of stratospheric bromine, Geophys. Res. Lett., 27 , 3695-3698, 2000.

Hebestreit, K., Stutz, J., Rosen, D., Matveeiv, V., Peleg, M., Luria, M., and Platt, U.: DOAS measurements of tropospheric bromine oxide in mid-latitudes, Science, 283, 55-57, 1999.

Hendrick, F., Mueller, R., Sinnhuber, B.-M., Bruns, M., Burrows, J. P., Chipperfield, M. P., Fonteyn, D., Richter, A., Van Roozendael, M., and Wittrock, F.: Simulation of BrO diurnal variation and $\mathrm{BrO}$ slant columns : Intercomparison exercise between three model packages, Proceedings of the 5th European Workshop on Stratospheric Ozone, Saint Jean de Luz, France, 27 Sept-1 Oct 
1999, Air Pollution Research Report $n^{\circ} 73$, European Commission - DG XII, Brussels, 2000.

Hendrick, F., Barret, B., Van Roozendael, M., Boesch, H., Butz, A., De Mazière, M., Goutail, F., Hermans, C., Lambert, J.-C., Pfeilsticker, K., and Pommereau, J.-P.: Retrieval of nitrogen dioxide stratospheric profiles from ground-based zenith-sky UVvisible observations: Validation of the technique through correlative comparisons, Atmos. Chem. Phys., 4, 2091-2106, 2004, http://www.atmos-chem-phys.net/4/2091/2004/.

Hendrick, F., Van Roozendael, M., Kylling, A., Petritoli, A., Rozanov, A., Sanghavi, S., Schofield, R., von Friedeburg, C., Wagner, T., Wittrock, F., Fonteyn, D., and De Mazière, M.: Intercomparison exercise between different radiative transfer models used for the interpretation of ground-based zenith-sky and multiaxis DOAS observations, Atmos. Chem. Phys., 6, 93-108, 2006, http://www.atmos-chem-phys.net/6/93/2006/.

Hoffman, D., Bonasoni, P., De Mazière, M., Evangelisti, F., Giovanelli, G., Goldman, A., Goutail, F., Harder, J., Jakoubek, R., Johnston, P., Kerr, J., Matthews, A., Mc Elroy, T., Mc Kenzie, R., Mount, G., Platt, U., Pommereau, J.-P., Sarkissian, A., Simon, P., Solomon, S., Stutz, J., Thomas, A., and Van Roozendael, M.: Intercomparison of UV/Visible spectrometers for measurements of stratospheric NO2 for the Network for the Detection of Stratospheric Change, J. Geophys. Res., 100, 16 765-16791, 1995.

Hönninger, G., von Friedeburg, C., and Platt, U.: Multi-axis differential absorption spectroscopy (MAX-DOAS), Atmos. Chem. Phys., 4, 231-254, 2004, http://www.atmos-chem-phys.net/4/231/2004/.

Lary, D. J., Gas phase atmospheric bromine photochemistry, J. Geophys. Res., 101(D1), 1505-1516, 1996.

Lee, A. M., Jones, R. L., Kilbane-Dawe, and Pyle, J. A.: Diagnosing ozone loss in the extratropical lower stratosphere, J. Geophys. Res., 107(D11), 4110, doi:10.1029/2001JD000538, 2002.

Leser, H., Hönninger, G., and Platt, U.: MAX-DOAS measurements of $\mathrm{BrO}$ and $\mathrm{NO}_{2}$ in the marine boundary layer, Geophys. Res. Lett., 30, 1537, doi:10.129/2002GL015811, 2003.

Kaleschke, L., Richter, A., Burrows, J. P., Afe, O., Heygster, G. Notholt, J., Rankin, A. M., Roscoe, H. K., Hollwedel, J., Wagner, T., and Jacobi, H. W.: Frost flowers on sea ice as a source of sea salt and their influence on tropospheric halogen chemistry, Geophys. Res. Lett., 31, L16114, doi:10.129/2004GL020655, 2004.

Kreher, K., Johnston, P. V., Wood, S. W., and Platt, U.: Groundbased measurements of tropospheric and stratospheric $\mathrm{BrO}$ at $\mathrm{Ar}-$ rival Heights (78 ${ }^{\circ}$ S), Antarctica, Geophys. Res. Lett., 24, 30213024, 1997.

McKenzie, R., Johnston, P. V., McElroy, C. T., Kerr, J. B., and Solomon, S.: Altitude distributions of stratospheric constituents from ground-based measurements at twilight, J. Geophys. Res., 96, 15 499-15 511, 1991.

Mayer, B. and Kylling, A.: Technical note: The libRadtran software package for radiative transfer calculations - description and examples of use, Atmos. Chem. Phys., 5, 1855-1877, 2005, http://www.atmos-chem-phys.net/5/1855/2005/.

Noxon, J. F.: Nitrogen dioxide in the stratosphere and troposphere measured by ground-based absorption spectroscopy, Science, 189, 547-549, 1975 .

Pfeilsticker, K., Sturges, W. T., Bösch, H., Camy-Peyret, C., Chipperfield, M. P., Engel, A., Fitzenberger, R., Müller, M., Payan, S., and Sinnhuber, B.-M.: Lower stratospheric organic and in- organic bromine budget for the arctic winter 1998/99, Geophys. Res. Lett., 27, 3305-3308, 2000.

Platt, U.: Differential Optical Absorption Spectroscopy (DOAS), in Air Monitoring By Spectroscopic Techniques, edited by: M. W. Sigrist, John Wiley and Sons, Inc., New York, 1994.

Preston, K. E., Jones, R. L., and Roscoe, H. K.: Retrieval of $\mathrm{NO}_{2}$ vertical profiles from ground-based UV-visible measurements: Method and validation, J. Geophys. Res., 102(D15), 19089 $19097,1997$.

Pundt, I., Pommereau, J.-P., Chipperfield, M. P., Van Roozendael, M., and Goutail, F.: Climatology of the stratospheric BrO vertical distribution by balloon-borne UV-visible spectrometry, J. Geophys. Res., 107(D24), 4806, doi:10.1029/2002JD002230, 2002.

Richter, A., Wittrock, F., Ladstätter-Weissenmayer, A., and Burrows, J. P.: GOME measurements of stratospheric and tropospheric BrO, Adv. Space Res., 29, 1667-1672, 2002.

Rodgers, C. D.: Inverse methods for atmospheric sounding, Theory and practice. World Scientific Publishing, Singapore-NewJerseyLondon-Hong Kong, 2000.

Roscoe, H. K., Johnston, P. V., Van Roozendael, M., Richter, A., Sarkissian, A., Roscoe, J., Preston, K. E., Lambert, J.-C., Hermans, C., Decuyper, W., Dzienus, S., Winterrath, T., Burrows, J. P., Goutail, F., Pommereau, J.-P., D’Almeida, E., Hottier, J., Coureul, C., Didier, R., Pundt, I., Bartlett, L. M., and Mc Elroy, C. T.: Slant column measurements of $\mathrm{O}_{3}$ and $\mathrm{NO}_{2}$ during the NDSC intercomparison of zenith-sky UV-visible spectrometers in June 1996, J. Atmos. Chem., 32, 281-314, 1999.

Salawitch, R. J., Weisenstein, D. K., Kovalenko, L. J., Sioris, C. E., Wennberg, P. O., Chance, K., Ko, M. K. W., and McLinden, C. A.: Sensitivity of ozone to bromine in lower stratosphere, Geophys. Res. Lett., 32, L05811, doi:10.129/2004GL021504, 2005.

Salawitch, R. J.: Biogenic bromine, Nature, 439, 275-277, 2006.

Sander, R., Keene, W. C., Pszenny, A. A. P., Arimoto, R., Ayers, G. P., Baboukas, E., Cainey, J. M., Crutzen, P. J., Duce, R. A., Hönninger, G., Huebert, B. J., Maenhaut, W., Mihalopoulos, N., Turekian, V. C., and Van Dingenen, R.: Inorganic bromine in the marine boundary layer: A critical review, Atmos. Chem. Phys., 3, 1301-1336, 2003, http://www.atmos-chem-phys.net/3/1301/2003/.

Sander, S. P., Friedl, R. R., Ravishankara, A. R., et al.: Chemical Kinetics and Photochemical Data for Use in Atmospheric Studies, Evaluation no 15, NASA JPL Publication no 06-2, 2006.

Schofield, R., Kreher, K., Connor, B. J., Johnston, P. V., Thomas, A., Shooter, D., Chipperfield, M. P., Rodgers, C. D., and Mount, G. H.: Retrieved tropospheric and stratospheric BrO columns over Lauder, New Zealand, J. Geophys. Res., 109, D14304, doi:10.1029/2003JD004463, 2004.

Schofield, R., Johnston, P. V., Thomas, A., Kreher, K., Connor, B. J., Wood, S., Shooter, D., Chipperfield, M. P., Richter, A., von Glasow, R., and Rodgers, C. D.: Tropospheric and stratospheric BrO columns over Arrival Heights, Antarctica, 2002, J. Geophys. Res., 109, D14304, doi:10.1029/2003JD004463, 2006.

Shettle, E. P.: Models of aerosols, clouds, and precipitation for atmospheric propagation studies, AGARD Conference Proceedings No. 454: Atmospheric propagation in the UV, visible, IR and mm-region and related system aspects, 1989.

Simpson W. R., Alvarez-Aviles, L., Douglas, T. A., Sturm, M., and Domine, F.: Halogens in the coastal snow pack near 
Barrow, Alaska: Evidence for active bromine air-snow chemistry during springtime, Geophys. Res. Lett., 32, L04811, doi:10.1029/2004GL021748, 2005.

Sinnhuber, B.-M., Arlander, D. W., Bovensmann, H., Burrows, J. P., Chipperfield, M. P., Enell, C.-F., Frieß, U., Hendrick, F., Johnston, P. V., Jones, R. L., Kreher, K., Mohamed Tahrin, N., Müller, R., Pfeilsticker, K., Platt, U., Pommereau, J.-P., Pundt, I., Richter, A., South, A. M., Tørnkvist, K. K., Van Roozendael, M., Wagner, T., and Wittrock, F.: Comparison of measurements and model calculations of stratospheric bromine monoxide, J. Geophys. Res., 107(D19), 4398, doi:10.1029/2001JD000940, 2002.

Sinnhuber, B.-M., Rozanov, A., Sheode, N., Afe, O. T., Richter, A., Sinnhuber, M., Wittrock, F., Burrows, J. P., Stiller, G. P., von Clarmann, T., and Linden, A.: Global observations of stratospheric bromine monoxide from SCIAMACHY, Geophys. Res. Lett., 32, L20810, doi:10.129/2005GL023839, 2005.

Sinnhuber, B.-M., Sheode, N., Sinnhuber, M., Chipperfield, M. P., and Feng, W.: The contribution of anthropogenic bromine emissions to past stratospheric ozone trends: A modelling study, Atmos. Chem. Phys. Discuss., 6, 6497-6524, 2006,

http://www.atmos-chem-phys-discuss.net/6/6497/2006/.

Theys, N., Van Roozendael, M., Hendrick F., Fayt, C., Hermans, C., Baray, J.-L., Goutail, F., Pommereau, J.-P., and De Mazière, M.: Retrieval of stratospheric and tropopsheric BrO columns from multi-axis DOAS measurements at Reunion Island, Atmos. Chem. Phys., 7, 4733-4749, 2007,

http://www.atmos-chem-phys.net/7/4733/2007/.

Vandaele, A. C., Fayt, C., Hendrick, F., Hermans, C., Humbled, F., Van Roozendael, M., Gil, M., Navarro, M., Puentedura, O., Yela, M., Braathen, G., Stebel, K., Tørnkvist, K., Johnston, P., Kreher, K., Goutail, F., Mieville, A., Pommereau, J.-P., Khaikine, S., Richter, A., Oetjen, H., Wittrock, F., Bugarski, S., Frieß, U., Pfeilsticker, K., Sinreich, R., Wagner, T., Corlett, G., and Leigh, R.: An intercomparison campaign of ground-based UV-Visible measurements of $\mathrm{NO}_{2}, \mathrm{BrO}$, and $\mathrm{OClO}$ slant columns. Methods of analysis and results for $\mathrm{NO}_{2}$, J. Geophys. Res., 110, D08305, doi:10.1029/2004JD005423, 2005.

Van Roozendael, M., Fayt, C., Hermans, C., and Lambert, J.-C.: Ground-based UV-visible Measurements of $\mathrm{BrO}, \mathrm{NO}_{2}, \mathrm{O}_{3}$ and OClO at Harestua $\left(60^{\circ} \mathrm{N}\right)$ since 1994 , Proceedings of the $4^{\text {th }}$ European Workshop on Polar Stratospheric Ozone, Schliersee, Germany, 22-26 Sept 1997, Air Pollution Research Report no 66, European Commission - DG XII, Brussels, 1998.

Van Roozendael, M., Fayt, C., Lambert, J.-C., Pundt, I., Wagner, T., Richter, A., and Chance, K.: Development of a bromine oxide product from GOME, Proceedings ESAMS '99-European Symposium on Atmospheric Measurements from Space, ESTEC, Noordwijk, The Netherlands, 18-22 January 1999, ESA WPP-161, 543-547, 1999.

Van Roozendael, M., Wagner, T., Richter, A., Pundt, I., Arlander, D., Burrows, J. P., Chipperfield, M., Fayt, C., Johnston, P. V., Lambert, J.-C., Kreher, K., Pfeilsticker, K., Platt, U., Pommereau, J.-P., Sinnhuber, B.-M., Tornkvist, K. K., and Wittrock, F.: Intercomparison of $\mathrm{BrO}$ measurements from ERS-2 GOME, ground-based and balloon platforms, Adv. Space Res., 29, 16611666, 2002. von Glasow, R., von Kuhlmann, R., Lawrence, M. G., Platt, U., and Crutzen, P. J.: Impact of reactive bromine chemistry in the troposphere, Atmos. Chem. Phys., 4, 2481-2497, 2004, http://www.atmos-chem-phys.net/4/2481/2004/.

Wahner, A., Ravishankara, A. R., Sander, S. P., and Friedl, R. R.: Absorption cross section of BrO between 312 and $385 \mathrm{~nm}$ at 298 and $223 \mathrm{~K}$, Chem. Phys. Lett., 152, 507-512, 1988.

Wagner, T., Leu, C., Wenig, M., Pfeilsticker, K., and Platt, U.: Spatial and temporal distribution of enhanced boundary layer $\mathrm{BrO}$ concentrations measured by the GOME instrument aboard ERS2, J. Geophys. Res., 106, 24 225-24 236, 2001.

Wagner, T., Burrows, J. P., Deutschmann, T., Dix, B., von Friedeburg, C., Frieß, U., Hendrick, F., Heue, K.-P., Irie, H., Iwabuchi, H., Kanaya, Y., Keller, J., Mc Linden, C. A., Oetjen, H., Palazzi, E., Petritoli, A., Platt, U., Postylyakov, O., Pukite, J., Richter, A., Van Roozendael, M., Rozanov, A., Sinreich, R., Sanghavi, S., and Wittrock, F. : Comparison of box-air-mass-factors and radiances for multiple-axis differential optical absorption spectroscopy (MAX-DOAS) geometries calculated from different UV/visible radiative transfer models, Atmos. Chem. Phys., 7, 1809-1833, 2007, http://www.atmos-chem-phys.net/7/1809/2007/.

Wilmouth, D. M., Hanisco, T. F., Donahue, N. M., and Anderson, J. G.: Fourier transform ultraviolet spectroscopy of the $\mathrm{A}\left({ }^{2} \Pi_{3 / 2}\right)$ $\leftarrow \mathrm{X}\left({ }^{2} \Pi_{3 / 2}\right)$ transition of BrO, J. Phys. Chem., 103, 8935-8945, 1999.

WMO: Scientific Assessment of Ozone depletion: 2002, World Meteorological Organization, Global Ozone Research and Monitoring Project, Report 47, 2003.

WMO: World Meteorological Organization Global Ozone Research and Monitoring Project-Report 50, 2007.

Yang, X., Cox, R. A., Warwick, N. J., Pyle, J. A., Carver, G. D., O'Connor, F. M., and Savage, N. H.: Tropospheric bromine chemistry and its impacts on ozone: A model study, J. Geophys. Res., 110, D23311, doi:10.1029/2005JD006244, 2005. 